\title{
Especialização em recursos naturais e cadeias globais de valor (1995 e 2009) *
}

\author{
Karine Aparecida Obalhe da Silva Piorski ${ }^{* *}$ \\ Clésio Lourenço Xavier ${ }^{* * *}$
}

\begin{abstract}
Resumo
O artigo propõe caracterizar a Especialização em Recursos Naturais no contexto de mudanças no comércio internacional. O mapeamento, feito a partir da decomposição das exportações do ano de 1995 e 2009 e Análise de Cluster, apontou o fortalecimento da integração produtiva regional dos países. Países da América do Norte, Europa e Ásia encontram-se inseridos em Cadeias de Valor, enquanto que os países latino-americanos, bem como a África do Sul, Arábia Saudita, dentre outros, estão limitadamente integrados em redes internacionais de produção como fornecedores de matérias-primas, com baixa capacidade de extrair valor das Cadeias de Produção em que estão inseridas. O desafio que se coloca para os países especializados em RN's é que, devido aos seus padrões de comércio ainda se caracterizarem como tradicionais, faz-se necessário romper com as restrições técnicas do setor, desenvolvendo a indústria de processos a fim de se inserirem em etapas mais avançadas do processo global de encadeamento de produção.
\end{abstract}

Palavras-chave: Recursos naturais; Especialização comercial; Cadeias globais de valor; Decomposição das exportações brutas; Vantagens comparativas em valor adicionado.

\section{Abstract \\ Specialization in natural resources and global value chains}

The paper proposes to characterize specialization in natural resources in the context of changes in international trade. In 1995 and 2009, the mapping, carried out from the decomposition of exports and cluster analysis, pointed to the strengthening of the regional productive integration of the countries. Countries in North America, Europe and Asia are inserted into value chains, while the Latin American countries, as well as South Africa, Saudi Arabia, among others, are limitedly integrated into international production networks as suppliers of raw materials with low capacity to extract value from the production chains in which they are inserted. The challenge for countries with natural resources is that they still have traditional trade patterns, therefore it is necessary to break the technical constraints of the industry, developing the process industry in order to insert these countries into more advanced stages of the production chain.

Keywords: Natural resources; Trade specialization; Global value chains; Decomposition of gross exports; Comparative advantages in value added.

JEL F10, F14, F60, F63.

\footnotetext{
* Artigo recebido em 11 de novembro de 2015 e aprovado em 25 de setembro de 2017.

** Professora do Curso de Ciências Econômicas da Universidade Estadual de Goiás (UEG), Goiânia, GO, Brasil. E-mail: karineobalhe@gmail.com.

*** Professor do Instituto de Economia e Relações Internacionais da Universidade Federal de Uberlândia
} (UFU), Uberlândia, MG, Brasil. E-mail: clesio@ufu.br. 


\section{Introdução}

Desde o fim da Segunda Guerra Mundial, estudiosos do comércio internacional chamam a atenção para mudanças na magnitude e natureza do intercâmbio de bens. $\mathrm{O}$ fato é que recorrentemente, desde então, a economia mundial passa por uma crescente fragmentação da produção, marcada pela separação geográfica - em dois ou mais países - das atividades envolvidas na produção de um bem ou serviço.

Mais especificamente, nos últimos 30 anos, o referido processo de internacionalização abriu precedentes para a atuação das Cadeias Globais de Valor $(\mathrm{CGV})$ - explicitando uma nova organização das empresas inseridas na divisão de processos produtivos verticalmente integrados, em novos e menores blocos produtivos com a finalidade de que a empresa se detenha preferencialmente em suas competências centrais, transferindo atividades secundárias para subsidiárias ou parceiros externos (Jones; Kierzkowski, 2000). Deste movimento, resulta um aumento substancial da interdependência entre as economias, traduzida num comércio mais intensivo de insumos e serviços intermediários e, portanto, sugere novas conformações do sistema produtivo e comercial dos países, e em maior grau, uma reconfiguração da divisão internacional do trabalho.

A referida natureza mutável do comércio internacional abre precedentes para se pensar na acomodação das mudanças no contexto competitivo dos países e regiões. Sob o entendimento de que, no contexto mais atual da dinâmica do comércio internacional, o conteúdo nacional é, recorrentemente, trocado pelo regional ou global, e a integração produtiva para além das fronteiras traz implicações para a capacidade manufatureira do país (capacidade de adicionar valor nos produtos), o artigo propõe caracterizar a especialização comercial de países em recursos naturais no contexto destas mudanças no comércio internacional.

O trabalho está estruturado em quatro seções. A primeira seção resgata brevemente a literatura de $\mathrm{CGV}$, pontuando a lógica de funcionamento da produção em rede, bem como sua natureza operacional. A segunda seção recupera brevemente, a literatura referente aos recursos naturais, tendo como foco as possibilidades de inserção deste ativo na lógica de funcionamento e natureza de operação da produção em rede. A terceira seção, traz as evidências referentes aos movimentos dos países e setores no referido contexto e, por fim, a última seção mostra a acomodação da produção em rede no contexto competitivo dos países e setores, de modo a caracterizar a especialização dos países, sobretudo daqueles especializados em recursos naturais. 


\section{Lógica de funcionamento e natureza de operação de uma produção em rede}

A presente seção recupera a lógica de funcionamento e natureza de operação da produção em rede, tendo em vista o aporte histórico-teórico das vantagens comparativas e padrões de comércio.

Não é consenso na literatura de comércio internacional que as especializações produtivas e comerciais são resultantes unicamente das vantagens comparativas e que estas trazem implicações para o bem estar econômico e a alocação eficiente dos fatores de produção.

Os tradicionais modelos baseados no livre comércio entendem as vantagens comparativas como sendo as vantagens de produção de bens que um país possui em relação ao outro ${ }^{1}$, e que o torna competitivo internacionalmente.

Tais vantagens são extraídas das diferenças entre preços ou custos de produção dos bens ofertados pelos países no comércio internacional, que por sua vez, estão relacionadas às diferenças de produtividade setoriais dos fatores de produção (capital e trabalho).

Por sua vez, as diferenças de produtividades dos fatores são explicadas pela abundância dos fatores de produção (H-O) no contexto de: a) mercados de bens e fatores regidos pela estrutura de mercado de concorrência perfeita; b) funções de produção: (i) similares às de outras nações envolvidas no comércio (ii) diferentes entre os setores produtivos e com (iii) rendimentos constantes de escala, significando que uma variação na utilização dos insumos pressupõe a mesma variação na produção.

Nesta via, devido à existência das vantagens comparativas, cada país se especializa na produção de bens diferentes e esta é a base (generalizada) na qual se concretiza o processo de troca entre os países. Isto acontece porque, devido ao jogo das livres forças de mercado, os agentes econômicos (atomizados), a partir das vantagens comparativas, alocam eficientemente os seus fatores de produção e, então, a especialização se define de acordo com perfis de eficiência produtiva desiguais entre os países, mas complementares (Moreira, 2012, p. 214).

Neste constructo teórico, as vantagens comparativas são presumidamente estáticas, significando que diante das vantagens de custos e preços e eficiência produtiva complementar, os países não têm incentivos para mudar suas estruturas de oferta e demanda: "cada um exporta o que produz mais eficientemente (oferta), e importa aquilo que não produz eficientemente (demanda)".

(1) As vantagens relativas são sinônimas das vantagens comparativas uma vez que o comércio internacional será mais vantajoso nos casos em que uma nação produz internamente a custos mais baixos do que outra nação, desde que, em termos, relativos, as produtividades de cada uma fossem relativamente diferentes. Este é um entendimento que se contrapõe à compreensão smithiana de vantagens absolutas: cada país deve especializar-se (completamente) em produtos que tem vantagens absolutas em termos de custos ou produtividade, ou seja, em que o número de horas de trabalho requerido para a sua produção é menor. 
A eficiência produtiva complementar define os padrões de especialização relativa de cada país e por meio do ajustamento em preços e quantidades, o nível de renda não se altera, maximizando riqueza (ou benefícios dos consumidores), dados os recursos e capacitações existentes.

Entretanto, as relações que se dão no âmbito do comércio internacional se tornam mais complexas a partir do reconhecimento do mercado como locus de confronto e rivalidade entre os agentes, marcado pela busca do poder e apropriação privada das vantagens absolutas (custos e qualidade). Neste quesito, os modelos tradicionais do livre comércio são relativizados pela ausência de tratamento dado ao processo concorrencial que ganha força a partir da constante criação e recriação de assimetria entre as unidades econômicas.

Se sob livre troca uma economia apresenta algum tipo de desenvolvimento tecnológico num setor que não aquele em que se observam vantagens comparativas iniciais, pode haver uma intervenção estratégica do país no sentido de reverter o padrão de especialização induzido pela vantagem comparativa e, neste caso, uma melhoria do bem-estar (Chenery, 1973; Redding, 1999).

Esta noção torna alusiva as vantagens comparativas dinâmicas a partir do relaxamento (por completo) das hipóteses de concorrência perfeita, retornos constantes de escala, mobilidade de fatores, difusão livre e imediata de tecnologia e funções de produção. E nesta linha, as vantagens comparativas, como único determinante de especialização comercial, seguem "relativizadas" em referenciais analíticos que realçam o papel das(os) (i) economias de escala (Novas Teorias do Comércio Internacional); (ii) diferenças tecnológicas entre os países (Hiatos tecnológicos); (iii) spillovers setoriais (Lucas, 1988; Romer, 1990) e); (iv) nível de gasto em P\&D (Grossman; Helpman, 1991); (v) das distintas intensidades do progresso técnico (Prebisch, 1949 e Singer, 1950); (vi) capacidades inovativas e imitativas dos países e grau de conhecimento tácito dos setores (Modelos Norte-Sul), (vii) de acordo com os rendimentos crescentes de escala (Kaldor, 1966), (viii) bens com diferenças em termos de elasticidade renda da demanda (Thirwall, 1979) e também, (ix) diferentes padrões de especialização tecnológicos (neoshumpterianos).

Neste diapasão, o comércio gera diferenças internacionais de crescimento da renda, mediante distintos tipos de especialização comercial existente. Isto porque, a vantagem relativa de um país vis a vis outros países, resulta não só das diferenças nacionais em relação às vantagens de dotação fatorial, mas também é uma função do diferencial tecnológico, conhecimento e capacidade que são criados e reproduzidos ao longo do tempo - as vantagens comparativas dinâmicas² ${ }^{2}$

(2) No decorrer do desenvolvimento do trabalho, o conceito de vantagens comparativas dinâmicas ganha amplitude na medida em que, para além do desenvolvimento tecnológico, ela é também entendida no desenvolvimento político e institucional de uma nação, por exemplo. Ao longo do tempo, as vantagens comparativas são problematizadas, já que são apresentados elementos críticos à noção convencional das vantagens comparativas (iniciais ou estáticas) e vantagens comparativas dinâmicas a partir do referencial da mudança tecnológica, apenas. 
O novo paradigma produtivo e comercial do início dos anos 80 até o período recente, relacionado à fragmentação da produção e Cadeias Globais de Valor, tornase um componente de importância crescente para se entender esta complexidade que está envolta nas vantagens comerciais como elemento propulsor de inserção competitiva (num cenário dinâmico por natureza) e desempenho econômico dos países.

Entendida como uma nova fase do processo de agregação de valor a um bem ao longo de sua cadeia produtiva, a fragmentação da produção pode ser levada a cabo por uma única firma, um conjunto de firmas de um mesmo país, ou ainda, por diferentes firmas estrangeiras, consolidando-se por meio da aquisição, via importação de insumos, peças e componentes necessários para a manufatura do produto final (Feenstra, 1988).

Em linhas gerais, este é um processo fomentado pelas estratégias corporativas de empresas que, primeiramente, se voltam para a superação da dicotomia terceirização versus verticalização (outsourcing) e depois, para a decisão entre produzir domesticamente ou externamente (offshoring), tendo como foco a redução de custos de produção, transação e ganhos de competitividade (Jones; Kierzkowski, 2000).

A segunda etapa (offshoring) depende, em larga escala, das vantagens comparativas específicas (locacionais ou verticais) que cada país possui. As tarefas ao longo do processo produtivo são cada vez mais fatiadas e específicas. Países que possuem vantagens comparativas em determinadas etapas (vantagens comparativas verticais) e possuem vantagem de custo de transporte irão apresentar maior inserção em cadeias do que outros que apresentam vantagens comparativas em outros setores (Nonnenberg, 2014; Beadreau, 2014).

A presença e variabilidade dos serviços torna-se parte indispensável desta integração produtiva ${ }^{3}$, pois permite uma maior flexibilidade no tocante ao envolvimento num maior número de cadeias produtivas, além de servir como uma "facilitação de comércio", no sentido de assegurar a conectividade (coordenação) das tarefas ou estágios de produção. Neste propósito, quanto mais custosa a oferta doméstica do serviço, em relação aos outros países, menor o incentivo à produção interna das tarefas que requerem tais serviços (Van Long et al., 2005).

No plano organizacional, por exemplo, o embarque de produtos em containers auxilia na logística de comércio e redução de custos de transportes, além de possibilizar uma série de inovações gerenciais que também reduzem custos e

(3) Entendida como um movimento de desintegração da produção com consequente integração das cadeias produtivas e comercial de diferentes países. 
melhoram a coordenação da produção a partir da automação, inter-mobilidade, rastreabilidade e maior segurança (WTO-IDE-Jetro, 2011).

No campo político, a liberalização comercial pode ter implicações na redução dos custos de comércio, por meio de (i) um maior acesso aos mercados (domésticos e internacionais) (ii) eficiência na administração de fronteiras (eficiência aduaneira, eficiência nos procedimentos de exportação e importação) e transparência na administração fronteiriça; (iii) desenvolvimento de infraestrutura de telecomunicações e transportes e, por fim, (iv) instauração de um ambiente propício a negócios (ambiente regulatório e instituições fortes, segurança física, políticas de investimentos, etc.) (Oliveira, 2014, p. 10).

No campo econômico e social considera-se importante a disponibilidade de insumos, mão de obra barata, mão de obra qualificada, infra estrutura (para facilitar o movimento de bens domesticamente e de maneira transfronteiriça), além de políticas de subsídios e de inovação (Oliveira, 2014, p. 10).

Assim, quanto mais tais elementos estão presentes num país, maior o diferencial de competitividade (na integração produtiva e comercial) para as empresas que se localizam neste país. Por outro lado, a ausência destes elementos pode atuar como "barreira" ao comércio e diminuir a atratividade do país para hospedar determinadas atividades de cadeia produtiva ${ }^{4}$, ensejando para o país, em muitos casos, a necessidade de uma nova forma de industrialização ou um novo modelo de desenvolvimento, pautado inclusive em políticas comerciais mais específicas para os elos e estágios da Cadeia (Nonnenberg, 2014; Oliveira, 2014).

Os elementos citados são determinantes críticos das vantagens comparativas de um país (Jones, 2006). E neste sentido, os parâmetros "valor adicionado nas exportações, conteúdo doméstico que retorna ao país e conteúdo estrangeiro contido nas exportações" qualificam a atuação na CGV - entendida como possibilidade de inserção na integração produtiva (na produção em rede), permanência (que é a atuação propriamente dita) e, ainda, a busca pelo upgrading ao longo da Cadeia.

A combinação entre baixo valor agregado estrangeiro e elevado valor adicionado doméstico reimportado, caracteriza uma posição upstream do país na integração produtiva. A presença de maior valor agregado estrangeiro atribui ao país uma posição downstrean (Koopman, 2012, p. 47).

Neste processo de adicionar valor em rede global, cabe lembrar que não são todos os setores que se integram, pois existem algumas características específicas que nem todos os setores produtivos possuem ou que possuem em termos diferenciados, como exemplo, a divisibilidade técnica do processo produtivo, a

(4) E neste caso as vantagens comparativas baseadas nos dotes fatoriais, somente, não funcionam como atrativo. 
intensidade do fator requerido no processo, a complexidade do processo produtivo e o peso específico dos produtos (Lall; Albaladejo; Mesquita, 2004).

A estratégia de industrialização dos países, bem como as especializações comerciais estabelecidas no contexto de comércio de bens finais, impõe um "filtro" ao potencial das firmas à adesão às CGV's. Países que mais se integraram às Cadeias são aqueles cujo modelo de desenvolvimento foi apoiado em export-oriented. Contrariamente, países que passaram pelos modelos de substituição de importações, demoraram ou até hoje não significativamente aderiram ao processo, pois estabeleceram prioridades ligadas à verticalização da produção dentro das fronteiras nacionais (Gereffi et al., 2005).

Para aqueles países inseridos na lógica das redes globais de valor, a participação também não sugere uma panaceia de atuação e desenvolvimento. Na condição de compradores globais, alguns países podem exercer poder sobre as empresas subcontratadas e participantes (pequenas e médias empresas de outros países), impondo parâmetros de contratos e subcontratos em sua cadeia de fornecimento. Tal poder pode estar baseado na propriedade de marcas bem estabelecidas no mercado, na propriedade de tecnologia ou na informação exclusiva acerca de diferentes mercados de produto, o que permite à firma atuar como um integrador de sistema ${ }^{5}$ (Altenburg, 2007).

O fato do país ou empresa concentrar suas atividades centrais, por exemplo, na pesquisa e desenvolvimento, vendas e desenvolvimento de marcas, e direcionarem as atividades manufatureiras para fornecedores independentes (geralmente, em outros países) que se mostram capazes de atender prazos, padrões de qualidade e especificações do produto, fazem com que ela retenha as atividades de maior valor agregado e capture considerável parcela dos retornos financeiros com a venda do produto final (Pietrobelli; Staritz, 2013).

Já um baixo grau de integração produtiva e comercial na CGV, ao longo do tempo, revela uma posição negociadora fraca de firmas (pequenas e médias) que em parte se explicam pela atuação em elos da Cadeia em que as barreiras à entrada de novos competidores são mais baixas, estando sujeitas a serem substituídas enquanto fornecedoras (Motta Veiga; Rios, 2015). Aliado a isto, está a possibilidade da hegemonia das firmas líderes terem "congelado" (lock-in) a posição de firmas subsidiárias em determinadas funções (tecnologicamente rasas) que agregam pouco valor e que são de baixa rentabilidade (Sturgeon; Kawakami 2010).

Diante disto, a lógica de funcionamento das CGV's realça as assimetrias de ambiente institucional e tecnológico entre os países participantes, levantando a

(5) Segundo Nonnemberg (2014) as firmas ficam sob comando mais ou menos centralizado de uma flagship company. 
possibilidade de esgotamento de melhorias do bem-estar social no longo prazo para países com pouca atuação na $\mathrm{CGV}$.

Acordos regionais e das regras preferenciais de origem tem influenciado sobremaneira estes modelos de comércio articulados no âmbito da CGV, principalmente no que diz respeito à composição das redes produtivas regionais. Para a região, além do estímulo permitir identificar os membros potenciais ao acordo, também indicam a possibilidade de acordos mais profundos e ambiciosos e o aumento da previsibilidade do ambiente político-institucional comercial, tão essenciais na lógica das CGV's (Oliveira, 2014, p. 106). Neste sentido, os acordos regionais influenciam os investimentos e níveis de participação na produção fragmentada, por meio de cadeias produtivas mais propícias à geração de ganhos entre eles (países) e para a região. E nesta esteira, os benefícios se estendem para as configurações industriais dos países que formam a região.

Posto isto, algumas características sobressaem de uma matriz de comércio das Cadeias de Valor: i) elas não são globais, são regionais em sua maioria; ii) a matriz é muito esparsa - poucos fluxos são relevantes em escala global; e iii) os Estados Unidos, Alemanha, Japão (Tríade) e a China dominam o comércio das cadeias em âmbito global (Baldwin, 2012; Estevadeordal; Blyde; Suominen, 2013).

Nas Cadeias regionais, grande parte do comércio de tarefas ou atividades acontece entre países vizinhos, o que identifica a origem do valor adicionado estrangeiro. Nesta via, como consequência de sua localização e extensão territorial e de suas opções de políticas comerciais, os países em desenvolvimento - África e América Latina - permanecem à margem do novo modo de organização da produção internacional, com baixo grau de competitividade medido pela inserção nas cadeias globais de valor (Motta; Veiga, 2012; Estevadeordal; Blyde; Suominen, 2013; Oliveira, 2014).

A título de considerações finais desta seção, não há razões suficientes para se afirmar, pela própria natureza das CGV's, que, mesmo que os países em desenvolvimento apresentem fatores atrativos para a produção fragmentada (vantagens comparativas), ao longo do tempo, terão oportunidades de modificação no seu sistema de produção e organizacional por meio de economias de escala, escopo, aprendizagem tecnológica, spillovers de conhecimento, robustez institucional, etc., de modo que sejam conduzidos ao catching up em relação aos países desenvolvidos, convergindo e ampliando os nível de renda.

Pensando em termos de upgrading na CGV - entendido como processo pelo qual uma empresa ou economia torna-se mais hábil a evoluir a nichos econômicos mais rentáveis e/ou tecnologicamente mais sofisticados e intensivos em conhecimento na produção de componentes ou bens intermediários - o catch-up 
tecnológico continua sendo o fim (desejado) a ser alcançado pelos países, conforme discutem os referenciais analíticos mais distantes do contexto liberal do comércio.

\section{Oportunidades de inserção/upgrading dos setores baseados em recursos naturais na lógica de funcionamento da produção}

A seção propõe recuperar a literatura que discute as vias de possibilidade de inserção/upgrading dos setores baseados em $\mathrm{RN}$ na lógica de funcionamento da produção.

Especulações teóricas e empíricas sobre o potencial dos recursos naturais liderarem um processo de desenvolvimento existem há pelo menos 40 anos, tendo notoriedade a dicotomia bênçãos e "maldição" dos recursos naturais. Porém, as novas configurações do comércio internacional, pautadas na fragmentação em rede e consequente integração produtiva e comercial, lançam no debate atual a noção de recursos naturais como oportunidade, no sentido de que eles ampliam as possibilidades de estratégias de desenvolvimento (diante de upgrading dentro do setor RN), ao mesmo tempo em que colocam novos desafios ao longo deste processo.

Os efeitos deletérios da dotação dos recursos naturais, que configuram a maldição dos recursos naturais, são aqui entendidos sob o ângulo das hipóteses Estruturalista, Doença Holandesa e Institucionalistas.

Do ponto de vista estruturalista, enquanto países centrais reúnem as economias com forte encadeamento setorial e elevada produtividade por meio de técnicas de produção que se difundem rapidamente à totalidade dos seus aparelhos produtivos $^{6}$, propiciando a diversificação e homogeneidade do setor de produção e uma baixa elasticidade-renda das exportações, a periferia é constituída por economias com estruturas produtivas heterogêneas na qual coexistem atividades de alta produtividade, como as atividades exportadoras (especializadas em recursos naturais), e demais atividades domésticas, baseadas em setores de baixa produtividade, dificultando a diversificação horizontal, a complementariedade intersetorial e a integração vertical (Reis, 2012).

Por sua vez, a manutenção ao longo do tempo (na periferia), de setores mais dinâmicos (como o de Recursos Naturais), que concomitantemente atuam ao lado de setores de baixa produtividade, gera um processo de acumulação de capital deficiente em toda a economia periférica e também, por vezes, inadequada intensidade de capital e de escala nos setores intensivos em recursos naturais. A dificuldade de agregar valor aos seus produtos e romper com a baixa elasticidaderenda das exportações tem implicações nas oscilações do valor das exportações e na

(6) Estas economias, em grande parte, tiveram como ponto de partida a especialização produtiva em recursos naturais, conforme apontam as experiências históricas e os estudos empíricos. 
capacidade para importar (deterioração dos termos de troca), causando o desequilíbrio externo - fatores limitadores de desenvolvimento (Maciel, 2014).

Desta forma, para os estruturalistas, o aumento de produtividade viria justamente da subida da escada tecnológica, migrando de atividades de baixa qualidade para as atividades de alta qualidade, rumo à sofisticação tecnológica da economia (Bresser-Pereira, 2005, p. 103). Para isso, a construção de um sistema industrial complexo e diversificado é fundamental, sujeito a retornos crescentes de escala, altas sinergias e linkages entre atividades (Reinert, 2010, p. 3).

Neste respeito, segundo Hirschman $(1958 ; 1977)$ os impulsos provocados pelos projetos de investimentos coordenados em setores específicos de países em desenvolvimento, promove consistentemente o aumento do ritmo de industrialização. Tais investimentos (estratégicos) teriam um efeito indutor, maximizando os efeitos de encadeamento (backwards and forwards linkages). Para tanto, é preciso que as ações aconteçam de maneira concentrada em projetos-chaves (investimentos) que favoreçam áreas (setores estratégicos) que já apresentem relativo dinamismo, pois o objetivo é potencializar os efeitos de fluência. Desta forma, justifica-se a intervenção do Estado nos países em desenvolvimento (Ribeiro; Rocha, 2013).

Tal intervenção pode se concentrar em efeitos de consumo (efeito demanda/multiplicador) e o efeito fiscal (renda gerada ao governo pela exportação de primários). Os administradores públicos e privados, ao identificarem tais efeitos, deverão estar mais propícios a executarem estímulos a determinada atividade produtiva que conduz ao crescimento e ao desenvolvimento. Em via de regra, os administradores devem priorizar estas atividades, pois entendem que quanto maiores os efeitos, maiores as possibilidades de surgimento de atividades complementares concatenadas, que podem repercutir em maior arrecadação fiscal, aumento da geração de empregos, etc. (Rippel; Lima; Borges, 2007; Reis, 2012; Maciel, 2014).

Este é um desafio para os setores exportadores de recursos naturais, pois, segundo Hirschman (1958), estes setores se mostraram fracos em encadeamentos, não sendo capazes de conferir um impulso dinâmico significativo para o desenvolvimento da economia.

Se, por um lado, a hipótese Estruturalista (anos 50) supõe que as economias são prejudicadas pelas baixas rendas oriundas do setor baseado em Recursos Naturais, a Doença Holandesa (anos 60, 70 e 80) assume a hipótese de que as economias dotadas de recursos ressentem-se também das elevadas receitas de suas exportações de RN's, com implicações na realocação de fatores de produção, na taxa de câmbio menos competitiva para produtos industrializados, com reflexos negativos nas exportações destes produtos e investimentos nos setores (aspectos macroeconômicos). 
A Doença Holandesa é, portanto, uma hipótese que vislumbra os efeitos deletérios da dotação dos recursos naturais no desenvolvimento dos países, desencadeados por um choque no setor baseado em recursos naturais (setor em expansão) via a) melhoramento técnico, expresso numa mudança favorável na função de produção, b) descoberta de novos recursos e ainda, c) aumento exógeno dos preços do produto no mercado internacional em relação ao preço das importações, tendo como principais consequências o aumento da renda agregada dos fatores de produção deste setor e a indução de dois efeitos: gasto e deslocamento.

O efeito gasto ocorre quando uma parte da renda "extra" gerada no setor de expansão (devido ao aumento das exportações) é gasta no setor de bens não comercializáveis. Em consequência de uma maior demanda pelos bens não comercializáveis, os seus preços se elevam em relação aos bens comercializáveis, causando uma apreciação da taxa de câmbio real (Bresser-Pereira, 2005).

Em consequência, o efeito deslocamento surge do fato de que o setor em expansão irá requerer mais trabalho, o que ocasiona o aumento da remuneração deste fator no setor. Isto desloca recursos produtivos (capital e trabalho) de outros setores da economia para o setor em expansão, tendendo a reduzir a produção nos setores comercializáveis (manufaturados) e não comercializáveis (Bresser-Pereira, 2005).

Como resultado conjunto destes dois efeitos, tem-se a perda da participação da atividade industrial na geração de produto e emprego. Nestes termos, a consequência perversa da dotação em recursos naturais advém da dificuldade da economia em obter taxas de crescimento mais elevadas e sustentadas no longo prazo em função do retrocesso ou do desmantelamento da estrutura produtiva da economia doméstica.

Numa perspectiva mais de longo prazo, o boom de recursos naturais com características transitórias revela uma situação mais problemática, em primeiro lugar porque o aumento da riqueza não é definitivo e, em segundo lugar, se no setor industrial existirem processos de learning by doing, as atividades que desaparecem durante o boom não poderão ser retomadas, afetando de maneira permanente as possibilidades de crescimento dos países (Bresser-Perreira, 2005a; Gala, 2006).

No caso do boom com características permanentes, o país em questão está estruturalmente mais rico do que no passado. Não obstante, ainda assim pode haver um efeito negativo no crescimento econômico, visto que o setor industrial é considerado o setor mais dinâmico da economia, na medida em que apresenta maior competitividade em relação aos setores baseados em recursos naturais, além de maiores possibilidades de incorporações tecnológicas e ganhos de produtividade. Se um setor apresenta rendimentos crescentes de escala, que não estejam presentes em outros setores, e maiores externalidades e "links" da cadeia produtiva, uma 
desindustrialização, de fato, afeta o crescimento econômico (Bresser-Perreira, 2005a; Gala, 2006).

Além disto, pode existir uma baixa capacidade do setor não comercializável e o setor baseado em recursos naturais em absorver todo o emprego que é dispensado no setor industrial, bem como a demanda por trabalhadores com o mesmo nível de qualificação daqueles dispensados do setor industrial (Bresser-Perreira, 2005a; Gala, 2006).

Os efeitos deletérios da maldição dos recursos naturais estão também na dimensão político-institucional de um país. Na medida em que, a apropriação das elevadas rendas oriundas da produção/exportação dos recursos naturais gera falhas políticas e institucionais e criam-se uma série de empecilhos ao crescimento de longo prazo (Ross, 1999).

Para a Nova Economia Institucionalista (NEI), a qualidade institucional é representada pela garantia de execução dos contratos, e neste ponto reside a noção de maldição dos recursos naturais. Recursos naturais abundantes e instituições fracas podem trazer consequências destrutivas para um país visto que dão margem a esforços para capturar privilégios de monopólios, concentrar poder político e econômico nas mãos de elites (do governo e setor privado), ilustrando comportamentos disfuncionais (rent seeking) no qual as rendas apropriadas são direcionadas às ações para seu próprio enriquecimento, ou atividades que buscam ampliar as chances de se manter no poder (patronagem) (Reis, 2012, p. 50).

E neste sentido, uma vez que as receitas do governo estão associadas, cada vez mais, às receitas de $\mathrm{RN}$, as políticas públicas também se tornam tendenciosas, mantendo o sistema produtivo operando no modelo vigente, o que significa que novas atividades econômicas são desestimuladas (Reis, 2012, p. 50).

Mais recentemente, um novo debate apresenta a inovação e suas forças propulsoras como um potencial de atuação das redes baseadas em recursos naturais, recolocando o contexto de produção e consumo de produtos baseados em RN, e a concepção de maldição dos recursos naturais.

As contribuições feitas por Carlota Perez para os países da América Latina, reafirmam as possibilidades de constituição de um núcleo dinamizador endógeno, capaz de explorar potencialidades e vantagens em RN no âmbito de cadeias produtivas. Nelas, doravante a acumulação de competências tecnológicas, há um processo de agregação de valor aos produtos e processos, com mudanças nas tendências dos preços relativos entre produtos manufaturados e recursos naturais.

A segmentação de mercado e de tecnologia são as forças que moldam o ambiente de atuação do setor RN de um país. Elas estão presentes nos estímulos ao processamento, diferenciação em produtos especiais e a montante, inovação de 
insumos, equipamentos, engenharia e ganhos de produtividade em toda a cadeia produtiva. Ao mesmo tempo em que a produção se torna cada vez mais especializada, o consumo do produto "natural" torna-se a preferência de um novo "consumidor" globalizado que procura produtos de características únicas (Perez, 2010, p. 37).

O resultado é uma gama de produtos baseados em $\mathrm{RN}$, desde os mais tradicionais até aqueles com tecnologias mais complexas e intensivas em conhecimento. Porém, esta é uma condição que depende de atividades internas à organização, e também de coordenação com outros elos de cadeias produtivas (Kaplinsky; Morris, 2000; Perez, 2010).

Com expressão desta organização e coordenação, as "competências medulares" tornam-se apêndices requeridos pelo setor baseado em $\mathrm{RN}$ e os processos de componetização, terceirização, ou compra de insumos de fornecedores especializados e selecionados (empresas cuja competência seja justamente neste componente) formatam uma estrutura industrial inovadora em RN de caráter local, regional ou global (Marin; Navas; Perez, 2012, p. 13).

A escolha por uma estratégia de desenvolvimento pautada no quadrante acima, coloca um país especializado em $\mathrm{RN}$ (e que tem a indústria de processos como motor estratégico) em condições favoráveis para a próxima revolução tecnológica, já em gestação, baseadas na combinação de biotecnologias, nanotecnologias, bioeletrônicos, novos materiais e fontes de energia (Perez, 2010, p. 16).

Apresentadas as principais ideias de Carlota Perez, cabe realçar a interação e ruptura entre esta autora e as visões mais tradicionais sobre as possibilidades de desenvolvimento liderado pelos recursos naturais.

Num primeiro diagnóstico, os pontos-chaves da discussão levantados pela autora recuperam a Teoria dos Staples ${ }^{7}$ (TS) e a teoria de Hirschman (1958), convergindo na importância atribuída a um setor estratégico (no caso, para Carlota Perez, é a indústria de processos) com relativo dinamismo, os encadeamentos setoriais (Hirschmann), o empreendedorismo (papel do setor privado e do Estado) e as transformações de mercado como estímulo ao desenvolvimento.

A Theory Staple estabelece que o crescimento econômico é iniciado pela demanda externa de Staples. Se os efeitos de transbordamento são potentes, a depender do tipo de Staples, as exportações crescem puxando outros setores domésticos. No curto e médio prazos, os estrangulamentos, que por ventura, surjam serão superados pela capacidade de importar fatores escassos, pela

(7) A Theory Staple é uma proposta de estudo dos recursos básicos, que nasceu no Canadá. Os estudos de Innis fundamentam a teoria Staples que baseia-se no estudo sobre as características do produto de exportação e o exame das relações entre os fatores locacionais e o desenvolvimento regional. O conceito Staples, contudo, trata apenas de exportações primárias. 
contenção dos vazamentos de renda para o exterior, bem como pela crescente oferta de empreendedorismo. No longo prazo, a capacidade de tração do setor externo tende a cessar, seja pelos retornos decrescentes da função de produção dos recursos naturais, seja por mudanças adversas pelo lado da demanda (competição com fontes de suprimentos mais baratas e substitutos). Assim, no longo prazo, a sustentabilidade do crescimento liderado por recursos naturais dependerá da capacidade de transformação do país, da sua habilidade em adequar seus recursos de acordo com as transformações do mercado (Maciel, 2015, p. 12).

Em complemento, entende-se que a habilidade para perceber e explorar as oportunidades de mercado pode ser atendida em parte por estrangeiros, mas a oferta de empreendedorismo doméstico - privado e governamental - é importante para as transformações na estrutura produtiva. Assim, o empreendedorismo doméstico depende da disponibilidade e qualidade da força de trabalho (gastos com educação, por exemplo), mas também de instituições e valores da sociedade, que são função das características dos Staples (Maciel, 2015, p. 12).

Um ponto de ruptura de Perez (2010) com os efeitos deletérios da dotação de recursos preconizados pelas hipóteses de maldição dos recursos, está na proposta da estratégia dual de desenvolvimento ${ }^{8}$, pois, a partir das estratégias a jusante e a montante, somadas ao papel das inovações e do Estado, há uma defesa de inversão da tesoura dos preços de Prebisch. Para Perez (2012, p. 77), a virtuosidade dos RN's está relacionada com a perda de expressividade das flutuações de preços dos recursos naturais exportados, uma vez que os produtos deixam de ser in natura e passam a ser commodities industriais (originados de complexas redes baseadas em recursos naturais).

\section{Evidência sobre os países e setores na lógica de funcionamento da produção em rede}

Nas seções anteriores falou-se de uma nova geografia que se desenha, modificando as relações produtivas e comerciais tradicionais de países desenvolvidos e em desenvolvimento no contexto de produção em rede. A presente seção apresenta as evidências referentes aos movimentos dos países e setores no

(8) Os trabalhos mais conhecidos que se contrapõem a esta questão são Rocha (2012) e Barbaletta, Robert e Yoguel (2012). Rocha (2012) recupera em seus argumentos o problema da Lei de Engel, que trata da "desutilidade marginal do produto baseado em recurso natural", ou seja, os produtos apresentam elasticidade-renda das exportações menor que 1 e esta elasticidade-renda é menor do que a elasticidade-renda de suas importações. Desta forma, segundo a visão do autor, não é trivial considerar que a acumulação do conhecimento em atividades intensivas em recursos naturais, promova de imediato a entrada em atividades que permitam a constante diferenciação e diversificação produtiva que expandam a demanda de produtos a taxas superiores ao crescimento da renda mundial (Rocha, 2012, p. 68). Para Barbaletta, Robert e Yoguel (2012) não há dúvidas de que há uma maior descentralização da estrutura organizacional das corporações globais, nem mesmo sobre a sua capacidade de inovação destas corporações, mas acredita-se que grande parte da inovação ainda se concentra no centro do sistema, nas matrizes ou filiais localizadas nas economias avançadas. 
contexto de produção em rede, como forma de ilustrar e caracterizar esta nova geografia.

No cenário atual de internacionalização produtiva, produtos intermediários correspondem ao mais importante fluxo de comércio, aproximadamente $40 \%$ do total comercializado (Unctad, 2013). Países mais "ativos" nesta estatística, normalmente apresentam convergência entre o valor adicionado estrangeiro e o valor doméstico adicionado nas exportações (Zhang; Schimanski, 2014).

A Figura 1 apresenta a média simples do valor agregado estrangeiro das exportações de países que formam uma região ${ }^{9}$, em particular para o ano de 1995 e 2009. Pode-se notar que, em média, os países da Europa exibem maior valor agregado estrangeiro (um indicativo de integração produtiva), seguidos pela Ásia Pacífico, América do Norte $^{10}$ e por último, América Latina.

\section{Figura 1}

Média do Valor Agregado Estrangeiro

(Participação nas Exportações Totais da Região - 1995 e 2009)

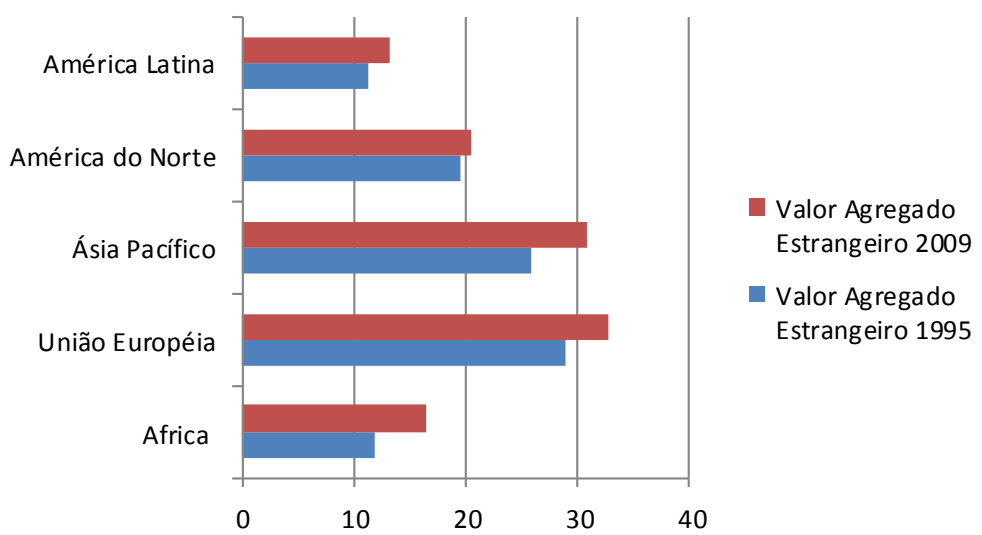

Fonte: Elaboração própria a partir de dados TiVA (2015).

A Tabela 1 mostra o valor agregado estrangeiro, Valor Doméstico Reimportado e Participação para frente (valor adicionado nas exportações de outros países) para os anos 1995 e 2009.

(9) As regiões são União Europeia (Alemanha, Áustria, Bélgica, Dinamarca, Eslováquia, Eslovênia, Espanha, Finlândia, França, Grécia, Hungria, Irlanda, Itália, Luxemburgo, Países Baixos, Polônia, Portugal, República Tcheca, Reino Unido e Suécia); Ásia Pacífico (Austrália, China, Cingapura, Coréia, Filipinas, Hong Kong, Indonésia, Japão, Malásia, Nova Zelândia, Tailândia e Vietnã); América do Norte (Estados Unidos, Canadá, México) e América Latina (Argentina, Brasil e Chile) e demais países.

(10) O valor relativamente pequeno do valor adicionado estrangeiro em produtos exportados pela América do Norte, em comparação com países da Ásia e Europa, é explicado pela extensão territorial de países como Estados Unidos e Canadá e pelo seu grau de industrialização (Estevadeordal; Blyde; Suominen, 2013, p. 20). 
Tabela 1

Valor Agregado Estrangeiro, Valor Doméstico Reimportado, Participação para Frente (1995 e 2009 - Participação no total das Exportações)

\begin{tabular}{|c|c|c|c|c|c|c|}
\hline & Valor Agregado Estrangeiro & Re-importação de Valor Agregado Doméstico & PF & PF \\
\hline & 1995 & $\mathbf{2 0 0 9}$ & $\mathbf{1 9 9 5}$ & $\mathbf{2 0 0 9}$ & $\mathbf{1 9 9 5}$ & $\mathbf{2 0 0 9}$ \\
\hline Africa & 11.75 & 16.49 & 0.03 & 0.02 & 31.51 & 17.33 \\
\hline União Europeia & 28.95 & 32.71 & 0.21 & 0.24 & 18.51 & 19.44 \\
\hline Ásia Pacífico & 25.76 & 30.83 & 0.11 & 0.30 & 15.94 & 24.12 \\
\hline América do Norte & 19.48 & 20.39 & 0.27 & 0.33 & 14.82 & 18.41 \\
\hline América Latina & 11.25 & 13.19 & 0.03 & 0.04 & 20.91 & 27.82 \\
\hline
\end{tabular}

Fonte: Elaboração Própria a partir de dados TiVA. PF: Participação para frente, ou seja, contribuição do país (valor agregado) nas exportações de outros países.

Pode-se perceber que, ao inserir na análise o Valor Doméstico Reimportado, a participação para frente da América do Norte aumenta, sobretudo em 2009. Na mesma linha estão os países da Ásia-Pacífico, seguidos pela União Europeia - ao apresentarem aumento de reimportação de valor agregado doméstico ao longo do tempo evidenciam também uma maior participação para frente na integração produtiva (Tabela 1).

Cabe destacar que, na mesma tabela, no ano de 1995, a participação para frente da Ásia Pacífico foi menor do que a participação para frente da União Europeia. Em 2009 esta situação se reverteu, sendo que a Ásia Pacífico ultrapassou a União Europeia, porém, as participações para frente destas duas regiões apresentaram valores menores do que a participação da América Latina (Tabela 1).

Neste propósito, se tratando da natureza da participação para frente da região América Latina e sua especialização em recursos naturais, a presença num processo de encadeamento de produção indica uma contribuição nas exportações de outros países pautada em insumos básicos - confirmado também pelos valores pouco expressivos de reimportação de conteúdo doméstico.

Portanto, Ásia Pacífico, União Europeia e América do Norte apresentam valores adicionados estrangeiros, reimportação de valor agregado doméstico e participação para frente que revelam um maior engajamento na integração produtiva fragmentada.

Os principais setores inseridos na lógica de integração produtiva regional estão expostos na Tabela 2 e 3. Observando os valores dos indicadores (RI, VAE e VAD) para 11 setores e 4 regiões e outros países, de um modo geral, tem-se a pouca expressividade da integração produtiva dos setores baseados em recursos naturais, com destaque para o setor de Mineração e Agricultura, Silvicultura, Caça e Pesca setores com os mais baixos valores de RI e VAE e elevados valores de VAD.

O setor de Madeira, Produtos do papel, Impressão e Publicação de países asiáticos e União Europeia, em 1995 e 2009, apresentam maiores valores de RI e VAE, em comparação com os setores de Agricultura, Mineração e Produtos alimentícios. Por sua vez, o setor Alimentício, Bebidas e Fumo de países norte- 
americanos se destacou em relação aos demais setores baseados em RN (Tabela 2 e 3), sobretudo em 2009.

De acordo com a Tabela 2 e 3, a combinação, maiores valores adicionados estrangeiros e reimportação de valores adicionados domésticos, sugere que o setor de Equipamentos ópticos e Eletroeletrônicos é o mais integrado à lógica da produção fragmentada, tanto em 1995 quanto em 2009. Ademais, analisando comparativamente este setor nos dois anos, é possível perceber que na Ásia houve um aprofundamento da integração produtiva e comercial deste setor.

Tal integração, conforme mostra a Tabela 4 (valores em dólares de valor adicionado por região), tem natureza regional, o que equivale a dizer que a Cadeia de Valor de Equipamentos Ópticos e Eletroeletrônicos está associada, em maior grau, à dinâmica regional asiática. Ainda de acordo com as Tabelas 2, 3 e 4, configura-se também na Ásia, a dinâmica regional de integração produtiva ligada ao setor Máquinas e Equipamentos e Equipamentos de Transporte ${ }^{11}$.

E ainda, na Tabela 5 (posições na CGV), a dinamização da Cadeia Regional de Valor da Ásia, principalmente em 2009, se expressa no melhor posicionamento (maior que 1) competitivo da China, Coréia, Japão, Taipé Chinesa e Austrália.

Retomando as Tabelas 2, 3 e 4, o setor Equipamentos de Transportes é o setor mais atuante no fenômeno de integração produtiva, que também tem natureza regional. Contudo, também não se deve desconsiderar a integração produtiva entre os países que compõem a União Europeia, nos setores Equipamentos Ópticos e Eletrônicos, Metais Básicos e Produtos Fabricados e Produtos Químicos e não metálicos.

Tabela 2

Indicadores TiVA - Setores e Regiões (1995)

\begin{tabular}{|c|c|c|c|c|c|c|c|c|c|c|c|c|c|c|c|}
\hline \multirow[t]{2}{*}{ INDICADORES 1995} & \multicolumn{3}{|c|}{ ASIA PACIFICO } & \multicolumn{3}{|c|}{ UNIAO EUROPEIA } & \multicolumn{3}{|c|}{ AMERICA DO NORTE } & \multicolumn{3}{|c|}{ AMERICA LATINA } & \multicolumn{3}{|c|}{ OUTROS } \\
\hline & $\mathrm{Rl}$ & VAE & VAD & Rl & VAE & VAD & $\mathrm{Rl}$ & VAE & VAD & $\mathrm{Rl}$ & VAE & VAD & Rl & VAE & VAD \\
\hline AGRICULTURA, SIVICUITURA, CAÇA E PESCA & 0.04 & 12.2 & 87.8 & 0.10 & 15.25 & 84.75 & 0.14 & 9.15 & 90.85 & 0.01 & 6.19 & 93.81 & 0.04 & 11.19 & 88.81 \\
\hline MINERAÇÃO & 0.05 & 18.89 & 81.11 & 0.10 & 16.50 & 83.51 & 0.13 & 7.90 & 92.10 & 0.01 & 6.44 & 93.56 & 0.03 & 9.33 & 90.67 \\
\hline ALIMENTOS BEBDDASEFUMO & 0.06 & 17.72 & 82.29 & 0.15 & 25.12 & 74.88 & 0.19 & 12.33 & 87.67 & 0.02 & 9.41 & 90.59 & 0.09 & 19.36 & 80.64 \\
\hline TEXTLL, COURRO VESTUARIOE CALCGDOS & 0.12 & 28.92 & 71.08 & 0.23 & 29.04 & 70.96 & 0.26 & 18.03 & 81.97 & 0.04 & 14.34 & 85.66 & 0.15 & 26.86 & 73.14 \\
\hline MADEIRA PRODUTOS DE PAPEL, IMPRESSÃO E PUBLICAÇĀO & 0.06 & 20.31 & 79.70 & 0.17 & 25.88 & 74.12 & 0.25 & 13.07 & 86.93 & 0.02 & 11.09 & 88.92 & 0.08 & 22.23 & 77.78 \\
\hline PRODUTOS QUIMICOSENÃO METALICOS & 0.09 & 33.88 & 66.10 & 0.22 & 32.09 & 67.91 & 0.25 & 16.87 & 83.13 & 0.05 & 19.55 & 80.45 & 0.14 & 25.66 & 74.34 \\
\hline METAIS BASICOS E PRODUTOS FABRICADOS & 0.08 & 26.36 & 65.34 & 0.26 & 33.74 & 66.26 & 0.37 & 19.81 & 80.19 & 0.06 & 15.47 & 84.53 & 0.15 & 25.53 & 74.50 \\
\hline MAQUINARIOE EQUUPAMENTOS & 0.11 & 30.66 & 69.34 & 0.22 & 30.11 & 69.89 & 0.30 & 20.58 & 79.42 & 0.04 & 16.72 & 83.28 & 0.11 & 25.14 & 74.92 \\
\hline EQUIPAMENTOS ELETROOPTICOS & 0.17 & 37.72 & 62.28 & 0.23 & 33.20 & 66.80 & 0.41 & 32.98 & 67.02 & 0.02 & 19.01 & 80.99 & 0.15 & 28.43 & 71.56 \\
\hline EQUIPAMENTOS DE TRANSPORTE & 0.07 & 29.31 & 70.66 & 0.34 & 35.94 & 64.07 & 0.45 & 27.39 & 72.61 & 0.07 & 21.96 & 78.04 & 0.13 & 28.40 & 71.60 \\
\hline TRANSFORMAÇÃO E RECICLAGEM & 0.10 & 27.52 & 72.48 & 0.20 & 26.45 & 73.56 & 0.31 & 20.29 & 79.71 & 0.01 & 9.69 & 90.30 & 0.09 & 22.03 & 77.97 \\
\hline
\end{tabular}

*VAE: Valor Adicionado Estrangeiro; VAD: Valor Adicionado Doméstico; RI: Reimportaçôes de Valor Adicionado Doméstico.

Fonte: Elaboração Própria a partir de Dados TiVA (1995 e 2009).

(11) O setor Maquinas e Equipamentos possui o segundo maior valor de RI e VAE, enquanto o setor Equipamentos e Transporte possui o segundo maior valor de RI e o quinto maior valor de VAE (Tabela 5). 
Tabela 3

Indicadores TiVA - Setores e Regiões (2009)

\begin{tabular}{|c|c|c|c|c|c|c|c|c|c|c|c|c|c|c|c|}
\hline \multirow[t]{2}{*}{ INDICADORES 2009} & \multicolumn{3}{|c|}{ ASIA PACIFICO } & \multicolumn{3}{|c|}{ UNIAO EUROPEAA } & \multicolumn{3}{|c|}{ AMERICA DO NORTE } & \multicolumn{3}{|c|}{ AMERICA LATINA } & \multicolumn{3}{|c|}{ OUTROS } \\
\hline & Rl & VAE & VAD & $\mathrm{Rl}$ & VAE & VAD & $\mathrm{Rl}$ & VAE & VAD & $\mathrm{Rl}$ & VAE & VAD & $\mathrm{Rl}$ & VAE & VAD \\
\hline AGRICULTURA, SIVICULTURA, CACA E PESCA & 0.06 & 14.43 & 85.59 & 0.13 & 20.81 & 79.19 & 0.28 & 14.00 & 86.00 & 0.03 & 10.50 & 89.50 & 0.09 & 12.85 & 87.15 \\
\hline MINERAÇĀO & 0.07 & 11.74 & 71.58 & 0.10 & 19.18 & 80.82 & 0.10 & 6.17 & 93.83 & 0.02 & 5.75 & 94.25 & 0.04 & 13.14 & 86.85 \\
\hline ALMENTOS BEBDDASE FUMO & 0.10 & 21.99 & 78.01 & 0.15 & 27.12 & 72.88 & 0.29 & 14.80 & 85.20 & 0.04 & 13.72 & 86.29 & 0.11 & 19.95 & 80.05 \\
\hline TEXTLL, COURRO VESTUARIOE EALCADOS & 0.18 & 30.73 & 69.27 & 0.21 & 33.28 & 66.72 & 0.44 & 21.47 & 78.53 & 0.05 & 17.50 & 82.49 & 0.16 & 27.10 & 72.91 \\
\hline MADEIRA PRODUTOS DE PAPEL, IMPRESSÃO E PUBLCACÇÃO & 0.13 & 24.45 & 75.55 & 0.17 & 28.52 & 71.48 & 0.23 & 14.10 & 85.90 & 0.05 & 15.00 & 85.00 & 0.12 & 24.64 & 75.36 \\
\hline PRODUTOS QUIMICOS ENÃOMETALICOS & 0.16 & 37.38 & 62.62 & 0.22 & 39.21 & 60.79 & 0.40 & 22.64 & 77.36 & 0.06 & 27.67 & 72.33 & 0.21 & 32.78 & 67.22 \\
\hline METAIS BASICOS E PRODUTOS FABRICADOS & 0.18 & 36.75 & 63.25 & 0.29 & 37.32 & 62.68 & 0.41 & 23.79 & 76.21 & 0.06 & 16.68 & 83.31 & 0.21 & 33.82 & 66.18 \\
\hline MÁQUINAS E EQUIPAMENTOS & 0.28 & 37.93 & 62.07 & 0.24 & 33.11 & 66.89 & 0.42 & 24.09 & 75.91 & 0.07 & 19.85 & 80.15 & 0.16 & 25.97 & 64.03 \\
\hline EQUIPAMENTOS OPTICOS EELETROELETRONNICOS & 0.60 & 43.32 & 56.68 & 0.26 & 41.56 & 58.44 & 0.51 & 33.31 & 66.69 & 0.03 & 14.82 & 85.18 & 0.26 & 32.68 & 67.32 \\
\hline EQUIPAMENTOS DE TRANSPORTE & 0.22 & 34.70 & 65.30 & 0.40 & 43.64 & 56.36 & 0.65 & 28.84 & 71.16 & 0.10 & 24.64 & 75.36 & 0.22 & 34.39 & 65.61 \\
\hline TRANSFORMAÇÃO E RECICLAGEM & 0.19 & 30.22 & 69.76 & 0.22 & 28.28 & 66.72 & 0.35 & 21.00 & 79.00 & 0.04 & 12.55 & 87.47 & 0.17 & 33.16 & 66.85 \\
\hline
\end{tabular}

*VAE: Valor Adicionado Estrangeiro; VAD: Valor Adicionado Doméstico; RI: Reimportações de Valor Adicionado Doméstico.

Fonte: Elaboração Própria a partir de Dados TiVA (1995 e 2009).

Conforme mostra a Tabela 5, a dinâmica das Cadeias Globais na União Europeia em grande parte é definida pela liderança (upstream) da Alemanha, mas também pela atuação da França, Holanda, Itália e Reino Unido.

No tocante à América do Norte, é notório que os Estados Unidos participam em maior grau do processo final da produção nas Cadeias de Valor de Equipamentos Ópticos e Eletrônicos, Equipamentos de Transportes e Máquinas e Equipamentos, sobretudo pelos elevados valores de RI e medianos valores de VAE (Tabelas 2, 3 e 4).

A América Latina, neste contexto, se apresenta como uma região posicionada no início das Cadeias de Valor (Tabela 5), atuando mais como fornecedora de insumos para empresas de outras origens adicionarem valor nas cadeias produtivas do que como exportadora de produtos com maior valor adicionado (Tabelas 2, 3 e 4). 
Tabela 4

Origem do Valor Adicionado por setor e região (1995 e 2009) (Em milhões de dólares)

\begin{tabular}{|c|c|c|c|c|c|c|c|c|c|c|}
\hline & \multicolumn{10}{|c|}{ Produtos Quimicos e Não Metálicos } \\
\hline & \multicolumn{2}{|c|}{ Asia Pacifico } & \multicolumn{2}{|c|}{ Uniao Europeia } & \multicolumn{2}{|c|}{ América do Norte } & \multicolumn{2}{|c|}{ América Latina } & \multicolumn{2}{|c|}{ Outros } \\
\hline & 1995 & 2009 & 1995 & 2009 & 1995 & 2009 & 1995 & 2009 & 1995 & 2009 \\
\hline Asia Pacifico & 61,695 & 176,520 & 3,578 & 11,681 & 44,778 & 90,012 & 1,420 & 3,271 & 5,444 & 12,825 \\
\hline Uniao Europeia & 2,894 & 8,669 & 75,198 & 148,380 & 1,627 & 3,944 & 0,323 & 0,720 & 3,086 & 5,903 \\
\hline América do Norte & 26,434 & 62,084 & 1,433 & 4,504 & 42,632 & 85,801 & 0,369 & 1,093 & 1,281 & 2,758 \\
\hline América Latina & 0,740 & 1,567 & 0,117 & 0,347 & 0,102 & 0,308 & 5,865 & 16,314 & 0,310 & 0,683 \\
\hline \multirow[t]{4}{*}{ Outros } & 2,088 & 8,397 & 1,248 & 4,530 & 0,611 & 1,666 & 0,255 & 1,123 & 35,319 & 104,971 \\
\hline & \multicolumn{10}{|c|}{ Têxtil, Calçados,Couro,Vestuarios } \\
\hline & \multicolumn{2}{|c|}{ Asia Pacifico } & \multicolumn{2}{|c|}{ Uniao Europeia } & \multicolumn{2}{|c|}{ América do Norte } & \multicolumn{2}{|c|}{ América Latina } & \multicolumn{2}{|c|}{ Outros } \\
\hline & 1995 & 2009 & 1995 & 2009 & 1995 & 2009 & 1995 & 2009 & 1995 & 2009 \\
\hline Asia Pacifico & 14,694 & 35,350 & 0,413 & 1,160 & 4,950 & 6,738 & 0,156 & 0,222 & 1,608 & 2,515 \\
\hline Uniao Europeia & 0,383 & 0,651 & 17,815 & 19,061 & 0,153 & 0,139 & 0,016 & 0,022 & 0,665 & 0,899 \\
\hline América do Norte & 2,847 & 4,170 & 0,070 & 0,088 & 4,600 & 6,020 & 0,016 & 0,020 & 0,122 & 0,190 \\
\hline América Latina & 0,114 & 0,213 & 0,033 & 0,051 & 0,031 & 0,031 & 2,458 & 3,058 & 0,075 & 0,109 \\
\hline \multirow[t]{4}{*}{ Outros } & 0,590 & 1,041 & 0,349 & 0,805 & 0,132 & 0,295 & 0,011 & 0,041 & 14,592 & 31,068 \\
\hline & \multicolumn{10}{|c|}{ Metais Básicos e Produtos Fabricados } \\
\hline & \multicolumn{2}{|c|}{ Asia Pacifico } & Unia & opeia & Amé & lorte & & tina & & \\
\hline & 1995 & 2009 & 1995 & 2009 & 1995 & 2009 & 1995 & 2009 & 1995 & 2009 \\
\hline Asia Pacifico & 39,951 & 109,292 & 2,986 & 8,136 & 30,327 & 39,708 & 3,075 & 13,693 & 6,400 & 10,574 \\
\hline Uniao Europeia & 2,284 & 5,889 & 52,829 & 91,762 & 1,584 & 2,013 & 0,209 & 0,474 & 2,133 & 4,302 \\
\hline América do Norte & 17,249 & 25,212 & 1,208 & 1,737 & 28,181 & 35,664 & 0,189 & 0,372 & 0,785 & 1,314 \\
\hline América Latina & 1,737 & 7,363 & 0,286 & 1,249 & 0,235 & 1,073 & 6,627 & 25,287 & 0,230 & 0,753 \\
\hline Outros & 1,849 & 6,013 & 0,958 & 2,483 & 0,464 & 0,994 & 0,073 & 0,211 & 16,470 & 29,969 \\
\hline & & & & & uipamento & nsporte & & & & \\
\hline & & & Unia & opeia & Amé & lorte & & tina & & \\
\hline & 1995 & 2009 & 1995 & 2009 & 1995 & 2009 & 1995 & 2009 & 1995 & 2009 \\
\hline Asia Pacifico & 43,234 & 106,492 & 1,594 & 4,745 & 26,396 & 48,009 & 0,143 & 0,496 & 2,617 & 7,160 \\
\hline Uniao Europeia & 0,968 & 2,938 & 35,140 & 70,680 & 25,485 & 1,439 & 0,038 & 0,142 & 0,887 & 3,381 \\
\hline América do Norte & 18,049 & 38,736 & 0,790 & 2,415 & 0,648 & 46,349 & 0,051 & 0,198 & 0,755 & 2,190 \\
\hline América Latina & 0,079 & 0,220 & 0,023 & 0,126 & 0,015 & 0,079 & 1,520 & 3,415 & 0,083 & 0,103 \\
\hline Outros & 0,545 & 1,950 & 0,155 & 1,566 & 0,051 & 0,234 & 0,015 & 0,079 & 4,711 & 21,099 \\
\hline & & & & & amentos ó & Eletrônico & & & & \\
\hline & & & Unia & opeia & Amé & lorte & & tina & & \\
\hline & 1995 & 2009 & 1995 & 2009 & 1995 & 2009 & 1995 & 2009 & 1995 & 2009 \\
\hline Asia Pacifico & 72,920 & 138,258 & 5,305 & 10,558 & 61,997 & 86,858 & 0,222 & 1,100 & 3,011 & 5,580 \\
\hline Uniao Europeia & 2,415 & 6,254 & 51,616 & 92,797 & 1,663 & 1,810 & 0,091 & 0,233 & 1,030 & 2,737 \\
\hline América do Norte & 33,559 & 46,979 & 2,311 & 3,491 & 55,223 & 80,343 & 0,132 & 0,545 & 0,793 & 1,420 \\
\hline América Latina & 0,059 & 0,315 & 0,020 & 0,778 & 0,053 & 0,096 & 1,303 & 3,732 & 0,033 & 0,107 \\
\hline Outros & 0,870 & 1,753 & 0,238 & 1,077 & 0,178 & 0,442 & 0,007 & 0,063 & 5,804 & 20,990 \\
\hline & & & & & láquinas e & entos & & & & \\
\hline & & & Unia & opeia & Amé & lorte & & tina & & \\
\hline & 1995 & 2009 & 1995 & 2009 & 1995 & 2009 & 1995 & 2009 & 1995 & 2009 \\
\hline Asia Pacifico & 28,857 & 69,662 & 1,268 & 3,548 & 27,246 & 39,451 & 0,229 & 0,816 & 2,038 & 5,815 \\
\hline Uniao Europeia & 1,827 & 5,446 & 51,761 & 100,071 & 1,232 & 2,051 & 0,198 & 0,403 & 1,314 & 4,248 \\
\hline América do Norte & 15,927 & 25,516 & 0,641 & 1,256 & 26,170 & 37,286 & 0,140 & 0,285 & 0,672 & 1,611 \\
\hline América Latina & 0,058 & 0,384 & 0,020 & 0,090 & 0,031 & 0,095 & 1,226 & 4,026 & 0,054 & 0,223 \\
\hline Outros & 0,414 & 1,474 & 0,136 & 0,821 & 0,068 & 0,259 & 0,014 & 0,071 & 3,925 & 15,016 \\
\hline & & & & Madeira, $\mathrm{p}$ & rodutos do & mpressão & ç̧ão & & & \\
\hline & & & Unia & opeia & Amé & lorte & & tina & & \\
\hline & 1995 & 2009 & 1995 & 2009 & 1995 & 2009 & 1995 & 2009 & 1995 & 2009 \\
\hline Asia Pacifico & 24,042 & 45,157 & 1,382 & 2,806 & 24,594 & 36,409 & 1,276 & 1,792 & 2,500 & 4,461 \\
\hline Uniao Europeia & 1,007 & 1,906 & 28,799 & 39,850 & 0,535 & 0,620 & 0,102 & 0,157 & 0,910 & 1,622 \\
\hline América do Norte & 13,610 & 23,112 & 0,802 & 1,566 & 23,938 & 35,570 & 0,145 & 0,248 & 0,462 & 1,080 \\
\hline América Latina & 0,742 & 1,057 & 0,108 & 0,238 & 0,065 & 0,130 & 3,979 & 7,943 & 0,096 & 0,919 \\
\hline Outros & 0,542 & 1,441 & 0,198 & 0,507 & 0,064 & 0,121 & 0,025 & 0,077 & 5,700 & 0,240 \\
\hline
\end{tabular}

Fonte: Elaboração própria a partir de dados TiVA (1995; 2009). 
Tabela 5

Posição na CGV- Regiões (1995 e 2009)

\begin{tabular}{|c|c|c|c|c|c|}
\hline UNIÃO EUROPÉIA & 1995 & 2009 & ÁSIA-PACIFICO & 1995 & 2009 \\
\hline Alemanha & 4.35 & 3.86 & China & 1.07 & 3.36 \\
\hline França & 2.24 & 1.6 & Coréia & 0.42 & 1.18 \\
\hline Holanda & 1.04 & 1.1 & Japão & 3.23 & 2.48 \\
\hline Itália & 1.19 & 1.21 & Chinese Taipei & 0.43 & 1.29 \\
\hline Reino Unido & 1.9 & 1.51 & Malásia & 0.66 & 0.99 \\
\hline \multirow[t]{2}{*}{ Demais países } & 0.43 & 0.47 & Austrália & 0.46 & 1.08 \\
\hline & & & Demais países & 0.24 & 0.4 \\
\hline AMÉRICA DO NORTE & 1995 & 2009 & AMÉRICA LATINA & 1995 & 2009 \\
\hline Estados Unidos & 5.41 & 5.14 & Argentina & 0.3 & 0.25 \\
\hline Canadá & 1.18 & 1.12 & Brasil & 0.5 & 0.56 \\
\hline México & 0.35 & 0.61 & Chile & 0.11 & 0.17 \\
\hline ÁFRICA & 1995 & 2009 & & & \\
\hline África do Sul & 0.26 & 0.1 & & & \\
\hline
\end{tabular}

Fonte: Elaboração própria a partir de dados TiVA.

Até aqui, foi possível perceber o retrato "final" do movimento de fragmentação da produção por parte dos países: a integração produtiva de caráter regional. De um modo geral, este movimento dos países mostra que o valor adicionado estrangeiro, em maior grau de origem regional, funciona mais como um complemento do que um substituto do valor adicionado doméstico, configurando uma nova divisão internacional do trabalho (Jones; Kierzkowski, 2000, p. 15).

Naquilo que foge do script na integração produtiva, está a América Latina, a África e seus recursos naturais e, não menos relevante, está o desafio de inserção no contexto. Isto se confirma diante da dinâmica do setor Madeiras, Produtos de papel, Impressão e Publicação. Este setor apresentou-se, dentre os setores baseados em RN, como setor com maior ${ }^{12}$ RI e VAE de países da União Europeia e América do Norte. Para a América Latina os valores foram inexpressivos (Tabela 2 e 3 ).

Tais achados abrem espaço para se pensar que não se vislumbrou, pelo menos no período considerado na análise, a ampliação das vantagens comparativas em indústrias de processos, como bem discute Carlota Perez, e/ou que não se rompeu com as dificuldades técnicas e econômicas implícitas na especialização dos recursos naturais que reportam, por exemplo, à Maldição dos Recursos Naturais. O fato é que, no conjunto dos países e setores pautados em $\mathrm{RN}$, as vantagens comparativas de caráter estático destoam da lógica de funcionamento da produção em rede.

\section{A produção em rede e o contexto competitivo dos países}

Nas seções anteriores vimos que as CGV's explicam boa parte das mudanças no funcionamento do comércio. Johnson e Noguera (2012), Koopman et al. (2012) e Belzberg (2014) têm proposto novas metodologias de análises sobre o comércio

(12) O setor Produtos Alimentícios, Bebidas e Fumo apresentaram os segundos maiores valores de RI e VAE. Lembrando que é uma comparação feita somente com os demais setores RN's. 
internacional e a competitividade dos países, a maioria centrada em novas propostas de indicadores. Mensurações tradicionais da dinâmica de comércio são baseadas em suposições de que as atividades de produção acontecem totalmente sob o arranjo produtivo de uma economia doméstica. No entanto, a intensificação da fragmentação da produção nas últimas décadas e o aumento do uso de insumos estrangeiros na produção, relativiza a compreensão das vantagens comparativas dos países.

A partir de uma amostra de 56 países extraídas da base de dados TiVA disponibilizada pela OCDE-WTO, optou-se neste trabalho por mapear as vantagens comparativas reveladas dos países no contexto de rede de produção global por meio do cálculo do Índice de Vantagens Comparativas Reveladas em Valor Adicionado. Enquanto o método tradicional de cálculo do VCR compara o Market Share de produtos/indústrias nacionais e estrangeiras, este último realça as vantagens comparativas de uma indústria de um país inserida na $\mathrm{CGV}$, definindo o caráter vertical das vantagens comparativas.

O cálculo do VCR valor adicionado foi feito da seguinte forma:

$$
V C R i j \mid z=\frac{\frac{X i j}{X j}}{\frac{X i z}{X z}} \equiv \frac{\frac{X i j}{X i z}}{\sum_{s=1}^{S} \frac{X i j}{X i z} \cdot \frac{X i z}{X z}} \equiv \frac{\frac{X i j}{X i z}}{\frac{X j}{X z}}
$$

Onde:

Xij é o valor adicionado nas exportações da indústria do país;

Xiz: é o valor adicionado nas exportações da indústria dos países;

$\mathrm{Xj}$ : é valor adicionado nas exportações do total de indústrias do país;

Xz: é o valor adicionado nas exportações do total de indústrias dos países.

O VCR valor adicionado descreve as características da produção de bens no contexto do comércio intermediário que acontece entre os países, visto que as exportações de valor adicionado (TiVA) se diferem das exportações brutas, na medida em que retiram das exportações o valor adicionado estrangeiro, que está contido nas exportações do país, bem como a reimportação de valor adicionado doméstico, ou seja, aquilo que cruza a fronteira do país por mais de uma vez. Neste quesito, o VCR valor adicionado mostra, de fato, a capacitação manufatureira do país, revelando o quanto um determinado fator de produção relacionado a determinada tarefa ou atividade (representando a propriedade de um bloco produtivo) é competitivo - vantagens comparativas verticais ${ }^{13}$.

(13) Cabe lembrar que a OCDE-WTO disponibiliza valores calculados de VCR' s valor adicionado, mas os cálculos, para os fins deste trabalho, foram refeitos, objetivando recortar a análise apenas para indústrias ligadas ao setor manufatureiro. Dado que os cálculos dos VCR's foram refeitos utilizando os valores de "Domestic Value Added embodied in gross exports" para os anos 1995 e 2009, foi possível calcular valores de VCR's também para Agricultura, Caça, Silvicultura e Pesca, uma vez que este trabalho tem como pretensão direcionar a análise para setores baseados em recursos naturais. 
Antes da apresentação do mapeamento, optou-se por uma análise descritiva dos VCR's valor adicionado. A distribuição de frequência de VCR's adicionados para 11 setores, nos anos de 1995 e 2009, mostra que diferentes valores explicitam informações sobre o nível de competitividade dos setores, ilustrando um caráter assimétrico da especialização comercial dos países (de caráter vertical).

Para o ano de 1995 (Figura 2), Máquinas e Equipamentos, Equipamentos de Transporte, Eletrônicos e Ópticos, Mineração extração e Madeira, Papel e Celulose apresentam uma maior concentração de países com VCR's menor que a unidade, ou seja, há um considerável número de países com desvantagem comparativa vertical nestes setores. Com relação aos setores de Máquinas e Equipamentos, Equipamentos de Transporte, Eletrônicos e Ópticos, a intensidade de capital e P\&D solicitadas por este tipo de setor pode explicar as dificuldades dos países em atingirem vantagens comparativas verticais (dinâmicas).

Figura 2

Distribuição de Frequências (1995)

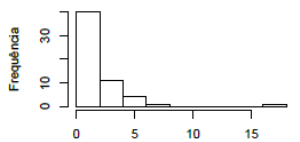

Agricultura, silvicultura, caça e pesca
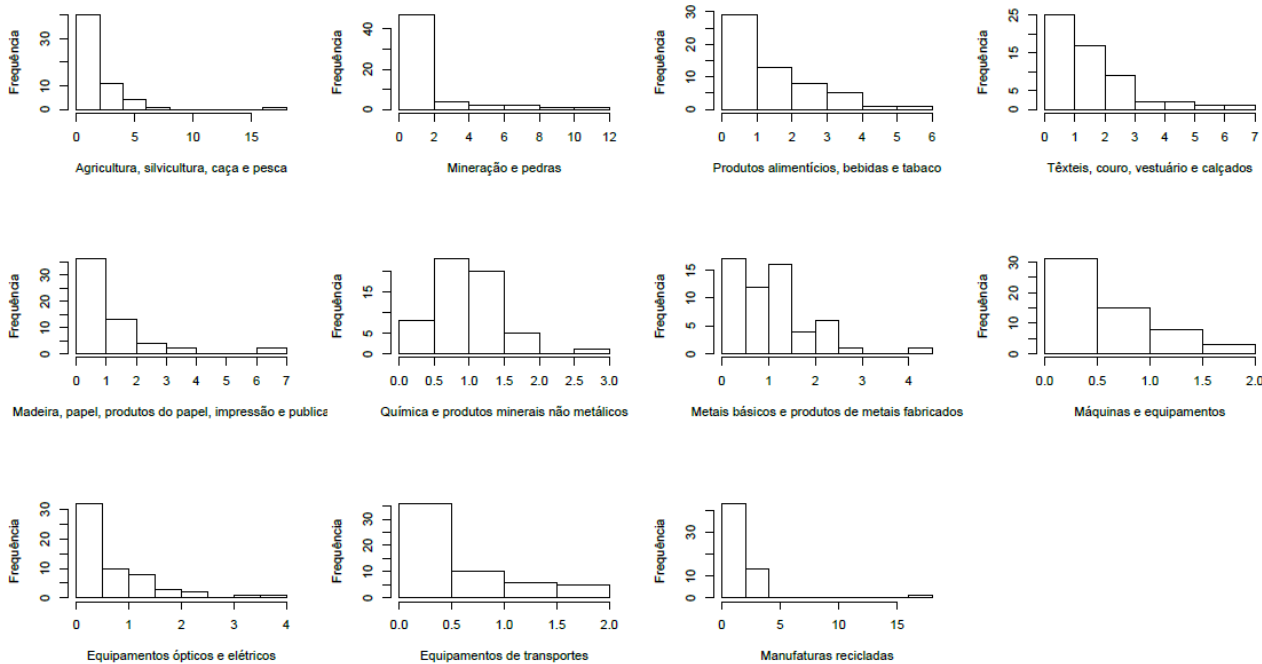

Fonte: Elaboração própria a partir de dados UNCTAD (2013). 
Figura 3

Distribuição de Frequências (2009)
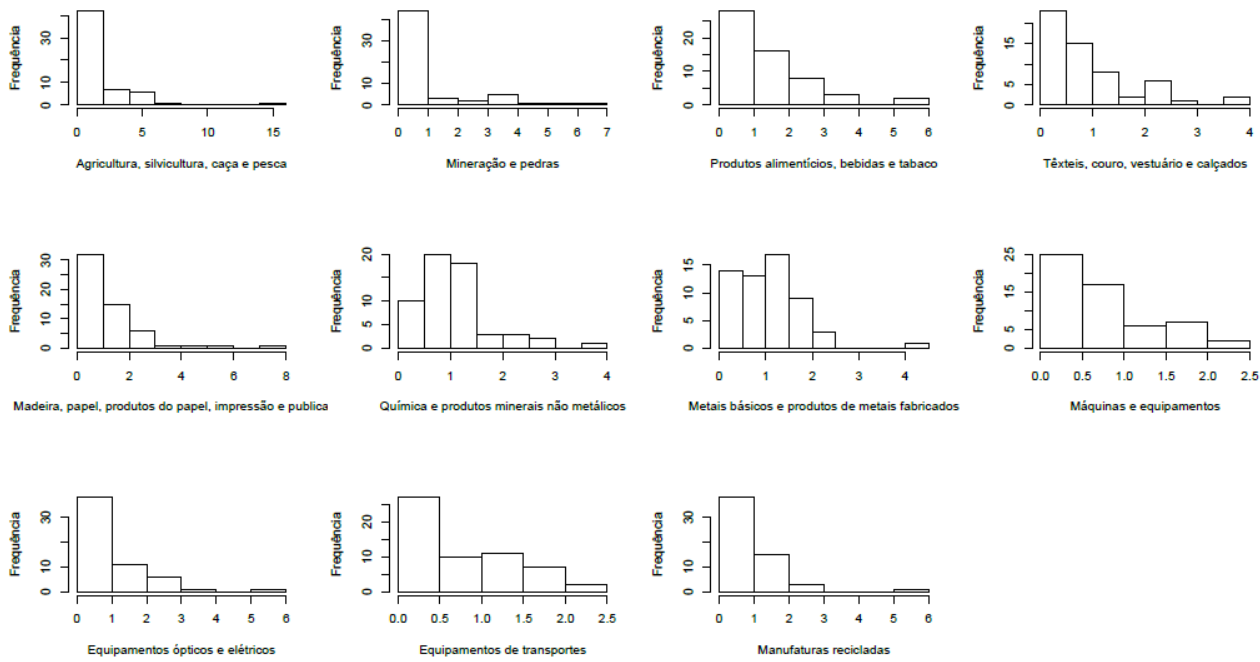

Fonte: Elaboração Própria a partir de dados UNCTAD (2013).

Já as indústrias de Madeira e Mineração sugerem um caráter estrutural da especialização - a dotação deste tipo de recursos naturais ou dificuldade, por parte de países, de desenvolver a indústria de processos.

No ano de 2009 (Figura 3), novamente o setor de Mineração e Extração, Indústria de Transformação e Reciclagem, Máquinas e Equipamentos, Equipamentos Eletrônicos e Ópticos, Equipamentos de Transportes e Madeira, Papel e Celulose apresentaram o maior número de países com desvantagens comparativas verticais. Comparativamente ao ano de 1995, o setor Têxtil, Couro, Vestuário e Calçados revela uma perda de especialização por parte de países, na medida em que diminui o número de países com vantagens comparativas verticais neste setor.

O setor Metais Básicos, Produtos Químicos, Produtos Alimentícios e Agricultura, Caça e Pesca, medianamente concentram países com VCR's maior e menor que a unidade. A Agricultura, Caça e Pesca estão diretamente relacionadas à dotação primária de recursos naturais, enquanto a indústria de alimentos de alguns países podem sugerir algum grau de "elaboração" desta dotação inicial de recursos ${ }^{14}$.

A fim de sugerir características estruturais intersetoriais dos VCR's, foi computada uma matriz de correlação, apresentada na Tabela 6. A matriz de Correlação mostra se a presença de VCR em dado setor está correlacionada com VCR's de outros setores (Hidalgo; Hausmann, 2011).

(14) Segundo Tabela de VCR Valor Adicionado Nova Zelândia, Brasil, Argentina, Vietnã, Chile, Austrália, França, Espanha Dinamarca, Grécia e Islândia são países especializados em Agricultura e Produtos Alimentícios. 
De acordo com a Tabela 6, no ano de 1995, Produtos Químicos e produtos minerais não metálicos, bem como Máquinas e Equipamentos e Equipamentos Elétricos e Ópticos apresentam correlação negativa com os recursos naturais (Agricultura, Mineração e Produtos alimentícios). Isso significa que, em geral, países que são especializados nestas indústrias apresentam valores de VCR's menores nos setores baseados em Recursos Naturais. Por fim, além da correlação negativa entre Têxteis e Mineração, existe a correlação negativa do setor Têxtil com Máquinas e Equipamentos.

No ano de 2009, mais uma vez se confirma a relação negativa entre Produtos Químicos e Agricultura, Caça e Pesca e Mineração e Extração. A relação também é negativa entre a Indústria baseada em RN (Agricultura, Mineração e Produtos Alimentícios) e Máquinas e Equipamentos, Equipamentos Eletrônicos e Ópticos e Equipamentos de Transportes.

A correlação entre o setor em Recursos Naturais sugere que quanto maior a especialização em Mineração, menor a especialização em Produtos Alimentícios, bebidas e fumo. Numa magnitude menor $(-0,06)$ quanto maior a especialização em Agricultura, Caça e Pesca, menor a especialização em Mineração e extração.

Têxteis, Couros, Vestuários e Calçados e Madeira e Produtos de papel apresentam correlação positiva com Agricultura e Produtos Alimentícios, Bebidas e Fumo, e uma correlação negativa, em maior grau, com Mineração e Extração e o setor de Produtos Químicos.

Tabela 6

Matriz de correlação VCR's (1995)

\begin{tabular}{|c|c|c|c|c|c|c|c|c|c|c|}
\hline & $\begin{array}{l}\text { Agricultura, } \\
\text { caça, } \\
\text { sivicultura e } \\
\text { pesca }\end{array}$ & $\begin{array}{l}\text { Mineração e } \\
\text { Extração }\end{array}$ & $\begin{array}{c}\text { Produtos } \\
\text { alimentícios, } \\
\text { bebidas e fumo }\end{array}$ & $\begin{array}{c}\text { Texteis, } \\
\text { vestuários, } \\
\text { couro e } \\
\text { calçados }\end{array}$ & $\begin{array}{c}\text { Madeira, } \\
\text { papel, } \\
\text { produtos de } \\
\text { papel, } \\
\text { impressão e } \\
\text { publicação } \\
\end{array}$ & $\begin{array}{l}\text { Produtos } \\
\text { Químicos e } \\
\text { produtos } \\
\text { minerais não } \\
\text { metálicos } \\
\end{array}$ & $\begin{array}{l}\text { Metais } \\
\text { básicos e } \\
\text { produtos } \\
\text { metálicos }\end{array}$ & $\begin{array}{l}\text { Máquinas e } \\
\text { Equipamentos }\end{array}$ & $\begin{array}{l}\text { Equipamentos } \\
\text { Elétricos e } \\
\text { Ópticos }\end{array}$ & $\begin{array}{l}\text { Equipamentos } \\
\text { de Transporte }\end{array}$ \\
\hline $\begin{array}{l}\text { Agricultura, caça, } \\
\text { sivicultura e pesca }\end{array}$ & 1 & -0.045 & 0.3052 & 0.1085 & -0.0924 & -0.3177 & -0.1918 & -0.2838 & -0.3332 & -0.2643 \\
\hline Mineração e Pedras & -0.045 & 1 & -0.1369 & -0.208 & -0.1315 & -0.3531 & -0.1491 & -0.3971 & -0.3787 & -0.2848 \\
\hline $\begin{array}{l}\text { Produtos alimentícios, } \\
\text { bebidas e fumo }\end{array}$ & 0.3052 & -0.1369 & 1 & 0.0227 & 0.006 & -0.1205 & -0.0998 & -0.2512 & -0.3023 & -0.224 \\
\hline $\begin{array}{l}\text { Texteis, vestuários, } \\
\text { couro e calçados }\end{array}$ & 0.1085 & -0.208 & 0.0227 & 1 & -0.1264 & -0.1828 & -0.0376 & -0.2473 & -0.144 & -0.1736 \\
\hline $\begin{array}{l}\text { Madeira, papel, produtos } \\
\text { de papel, impressão e } \\
\text { publicação }\end{array}$ & -0.0924 & -0.1315 & 0.006 & -0.1264 & 1 & -0.1485 & 0.0187 & 0.1145 & -0.1619 & -0.0146 \\
\hline $\begin{array}{c}\text { Produtos Químicos e } \\
\text { produtos minerais não } \\
\text { metálicos }\end{array}$ & -0.3177 & -0.3531 & -0.1205 & -0.1828 & -0.1485 & 1 & 0.2006 & 0.3245 & 0.1961 & 0.0701 \\
\hline $\begin{array}{l}\text { Metais básicos e } \\
\text { produtos metálicos }\end{array}$ & -0.1918 & -0.1491 & -0.0998 & -0.0376 & 0.0187 & 0.2006 & 1 & 0.1966 & -0.2858 & 0.1346 \\
\hline $\begin{array}{c}\text { Máquinas e } \\
\text { Equipamentos }\end{array}$ & -0.2838 & -0.3971 & -0.2512 & -0.2473 & 0.1145 & 0.3245 & 0.1966 & 1 & 0.1701 & 0.4049 \\
\hline $\begin{array}{c}\text { Equipamentos Elétricos e } \\
\text { Ópticos }\end{array}$ & -0.3332 & -0.3787 & -0.3023 & -0.144 & -0.1619 & 0.1961 & -0.2858 & 0.1701 & 1 & 0.1453 \\
\hline $\begin{array}{l}\text { Equipamentos de } \\
\text { Transporte }\end{array}$ & -0.2643 & -0.2848 & -0.224 & -0.1736 & -0.0146 & 0.0701 & 0.1346 & 0.4049 & 0.1453 & 1 \\
\hline $\begin{array}{l}\text { Indústria transformação, } \\
\text { nec. Reciclagem; }\end{array}$ & -0.1079 & -0.1871 & -0.1209 & 0.1126 & -0.087 & -0.0515 & -0.0981 & -0.0357 & 0.0564 & -0.087 \\
\hline
\end{tabular}

Fonte: Elaboração própria a partir de dados OCDE/TiVA. 
Tabela 7

Matriz de Correlação VCR's (2009)

\begin{tabular}{|c|c|c|c|c|c|c|c|c|c|c|c|}
\hline & $\begin{array}{l}\text { Agrivulura, caça, } \\
\text { s viviculura e pesca }\end{array}$ & $\underset{\text { Pedras }}{\text { Minerąão e }}$ & $\begin{array}{l}\text { Produtos } \\
\text { a limentíios, } \\
\text { bebidas e fumo }\end{array}$ & $\begin{array}{l}\text { Texte is, } \\
\text { vestuarios, } \\
\text { couroe } \\
\text { calsados }\end{array}$ & $\begin{array}{c}\text { Madeira, pape1, } \\
\text { produtos de } \\
\text { papet, } \\
\text { impressẫo e } \\
\text { publicação }\end{array}$ & $\begin{array}{l}\text { Produtos } \\
\text { Quimicose } \\
\text { produtos } \\
\text { minerais não } \\
\text { metálicos }\end{array}$ & $\begin{array}{c}\text { Metais } \\
\text { bisicose } \\
\text { produtos } \\
\text { metilicos }\end{array}$ & $\begin{array}{c}\text { Máquina } \\
\text { se } \\
\text { Equipame } \\
\text { ntos }\end{array}$ & $\begin{array}{c}\text { Equipamentos } \\
\text { Elétricos e } \\
\text { Opticos }\end{array}$ & $\begin{array}{c}\text { Equipamentos de } \\
\text { Transporte }\end{array}$ & $\begin{array}{c}\text { Indústria } \\
\text { uransformaçäo, } \\
\text { nec. } \\
\text { Reciklagemy }\end{array}$ \\
\hline $\begin{array}{c}\text { A gricultura, caça, sivicultura } \\
\text { e pasca }\end{array}$ & 1 & -0.0653 & 0.4939 & 03162 & 0.1076 & -0.2949 & -0.1517 & -0.3496 & -0.3283 & -02635 & -0.0584 \\
\hline M inera ção e Pedras & -0.0653 & 1 & -0.1944 & -0.2026 & -0.1885 & -0.4062 & -0.2606 & -0.4442 & -0.4226 & -0.394 & -0.3387 \\
\hline $\begin{array}{l}\text { Produtos alimenticios, } \\
\text { bebidas e fumo }\end{array}$ & 0.4939 & -0.1944 & 1 & 0.1333 & 0.1597 & 0.0093 & -0.1042 & -0.2419 & -0.3741 & -0.242 & -0.0246 \\
\hline $\begin{array}{l}\text { Texteis, vestuários, couso e } \\
\text { caks ados os }\end{array}$ & 0.3162 & .02026 & 0.1333 & 1 & -0.0469 & -0.325 & 0.1182 & -0.1562 & -0.0585 & -0.0646 & 0.35 \\
\hline $\begin{array}{l}\text { Madeira, papel, produtos de } \\
\text { papet, impressâo e publicaçấ }\end{array}$ & 0.1076 & -0.1885 & 0.1597 & -0.0469 & 1 & -0.154 & 0.1295 & 0.1287 & -0.1835 & -0.1103 & 0.1336 \\
\hline $\begin{array}{l}\text { Produtos Quimicos e } \\
\text { produtos minerais nă } \\
\text { metatitios }\end{array}$ & -0.2949 & -0.4062 & 0.0093 & -0.325 & -0.154 & 1 & 0.0139 & 0.2096 & 0.1246 & 0.0218 & -0.0622 \\
\hline $\begin{array}{c}\text { Metais básicos e produtos } \\
\text { metálizos }\end{array}$ & -0.1517 & .02606 & -0.1042 & 0.1182 & 0.1295 & 0.0139 & 1 & 0.3285 & -0.2305 & 0.255 & 0.0777 \\
\hline Máquinas e Equipamentos & -0.3496 & -0.4442 & -0.2419 & -0.1562 & 0.1287 & 02096 & 03285 & 1 & 0.1197 & 0.4589 & 0.1048 \\
\hline $\begin{array}{c}\text { Equipamentos Elésricos e } \\
\text { Opticos }\end{array}$ & -0.3283 & -0.4226 & -0.3741 & -0.0585 & -0.1835 & 0.1246 & -0.2305 & 0.1197 & 1 & 0.141 & 0.0927 \\
\hline Equipamentos de Transporte & -0.2635 & -0.394 & -0.242 & -0.0646 & -0.1103 & 0.0218 & 0.255 & 0.4589 & 0.141 & 1 & 0.1671 \\
\hline $\begin{array}{l}\text { Indús tria transformação, nec. } \\
\text { Reciclagem; }\end{array}$ & -0.0584 & -0.3387 & -0.0246 & 035 & 0.1336 & -0.0622 & 0.0777 & 0.1048 & 0.0927 & 0.1671 & 1 \\
\hline
\end{tabular}

Fonte: Elaboração própria a partir de dados da OCDE/TiVA (2014).

De um modo geral, como resultado da lógica de funcionamento da fragmentação da produção nas duas últimas décadas, temos destaque para o setor de Eletroeletrônicos, Produtos Químicos e Equipamentos de Transportes. A frequência do VCR valor adicionado mostrou que um menor número de países tem vantagens comparativas verticais em Eletrônicos e Equipamentos de Transporte, e comparativamente, um número maior de países tem vantagens comparativas verticais em Produtos Químicos e Produtos Minerais não metálicos. Além disto, quando os países apresentam vantagens comparativas verticais em Eletrônicos e Equipamentos de Transporte, estes países possuem menores VCR's no setor baseado em Recursos Naturais. Do mesmo modo, os Produtos Químicos e Produtos Minerais não metálicos apresentam correlação negativa com setores básicos, tais como: Agricultura, Mineração, Têxteis e Madeira, também apresentam correlação positiva com Máquinas e Equipamentos - setor que indica estrutura produtiva mais desenvolvidas.

Assim, reconhecem-se como elemento intrínseco às configurações da CGV, padrões semelhantes de fragmentação e integração produtiva que podem ser observados entre grupos de países que reúnem fatores de produção para o desempenho de tarefas ou atividades parecidas e com níveis de competitividade (agregação de valor) similares, o que pode ser ilustrado pela análise de cluster.

Segundo Gimenes et al. (2003), o princípio da análise de agrupamento (cluster) consiste em que cada observação de uma amostra multivariada possa ser considerada como um ponto em um espaço euclidiano multidimensional. Os processos de classificação objetivam agrupar esses pontos em conjuntos que evidenciem aspectos marcantes da amostra. Assim, dado um conjunto de observações conhecidas somente por uma listagem de suas características, objetivase encontrar a melhor maneira de descrever seus padrões de similaridade mútuos. 
Assim sendo, o agrupamento ou análise de cluster pretende-se, dada uma amostra de $\boldsymbol{n}$ objetos (ou indivíduos), cada um deles medidos segundos $\boldsymbol{p}$ variáveis, procurar um esquema de classificação que agrupe os objetos em $\boldsymbol{g}$ grupos, exigindose daí conceitos científicos mais sofisticados de semelhança. Devem ser determinados também o número e as características desses grupos (Bussab; Miazaki; Andrade, 1990). Nestas condições, tem-se satisfeita a viabilidade do mapeamento dos setores e indústrias proposto neste trabalho, já que $\boldsymbol{n}$ (número de indivíduos, neste caso países) tem que ser maior que $\boldsymbol{p}$ (número de variáveis: dez indústrias).

Os diversos métodos de agrupamento objetivam transformar um conjunto heterogêneo de unidades não separadas, a princípio, em grupos que reflitam aspectos considerados importantes das relações originais entre as mesmas unidades (Gimenes et al., 2003). Para isso são propostas muitas técnicas, não se estruturando ainda uma teoria geral e amplamente aceita.

A análise de agrupamento é interessante, principalmente sob o aspecto descritivo, pois seu resultado final, nos métodos, gera um gráfico de esquemas hierárquicos denominado dendrograma, que é empregado, mais comumente, para ilustrar o arranjo de grupos derivados da aplicação de um algoritmo de agrupamento (Landim, 2001).

De acordo com Alencar et al. (2013), um conceito fundamental na utilização das técnicas de Análise de Agrupamento é a escolha de um critério que meça a distância entre dois objetos, ou que quantifique o quanto eles são parecidos. Esta medida é chamada de coeficiente de parecença. Tecnicamente, é possível dividir esta medida em duas categorias: medidas de similaridade e de dissimilaridade.

$\mathrm{Na}$ medida de similaridade, quanto maiores os valores observados, mais parecidos serão os objetos. Já para a medida de dissimilaridade, quanto maiores os valores observados, menos parecidos (mais dissimilares) serão os objetos. A maioria dos softwares estatísticos que realizam algoritmos de análise de agrupamento já estão programados para operarem com o conceito de distância (dissimilaridade).

Entre as medidas de dissimilaridade existentes na literatura, a distância euclidiana e a distância de Mahalanobis $\left(\mathrm{D}^{2}\right)$ são as mais utilizadas. Um dos inconvenientes apresentados pela Distância Euclidiana é o fato de ela ser alterada com a mudança de escala de medições e de não levar em conta o grau de correlação entre eles. No entanto, para contornar o problema de escala, tem sido recomendada a padronização dos dados (Cruz; Regazzi, 1997).

No presente estudo, o grau de correlação entre as variáveis não foi significativo, sendo isso avaliado por meio do teste de Correlação de Pearson. Logo, não houve a necessidade de utilização da Distância $\mathrm{D}^{2}$. Para contornar o problema de escala, foi aplicada a padronização nos dados.

Após a escolha das variáveis que serão usadas como critérios de semelhança, uma das questões vitais das técnicas de análise de agrupamento é a definição do 
coeficiente de similaridade ou dissimilaridade, que irá incorrer em formação de agrupamentos.

A formação de agrupamentos fundamenta-se em duas ideias básicas sugeridas por Bussab, Miazaki e Andrade (1990) que são: coesão interna dos objetos e isolamento externo entre os grupos. Na literatura, existem maneiras diferentes para medir as duas ideias, daí a existência de grande número de algoritmos para formar grupos como apresentam Bussab, Miazaki e Andrade (1990), Mardia (1989) e Johnson e Wichern (1982).

Dentre os métodos existentes, o método de Ward foi utilizado pelo fato de maximizar a homogeneidade dentro dos grupos, ou minimizar o das somas de quadrados dentro de grupos, também conhecida como soma de ESS. Em cada passo do procedimento, são formados grupos de tal modo que a solução resultante tenha a menor soma de quadrados dentro de cada grupo. Usa a soma de quadrados (SQ) dentro dos agrupamentos como um critério de agrupamento.

$$
E_{(G 1 G 2)}=\sum_{V}^{P} \sum_{\substack{i=1 \\ i \in G 1}}^{n}\left(x_{i v}-\bar{x}_{v}\right)^{2}
$$

De um modo geral, o Método de Ward: Maximiza as diferenças entre os agrupamentos, é menos influenciado por outliers ou ruídos, pode ser usado para inicializar o método da K-médias, e para cada grupo, a soma de quadrados é calculada. Os dois grupos com os menores valores de SQ serão unidos.

As técnicas de agrupar podem ser classificadas em categorias, nas quais as técnicas hierárquicas são as mais utilizadas na literatura. Nessas técnicas hierárquicas, os objetos são classificados em grupos, em diferentes etapas, de modo hierárquico, produzindo uma árvore de classificação.

Os agrupamentos são feitos utilizando todas as variáveis disponíveis e representados de maneira bidimensional através de um dendrograma (diagrama bidimensional em forma de árvore). Nele estão dispostas linhas ligadas segundo os níveis de similaridade, que agruparão pares de indivíduos ou de variáveis, segundo Everitt (1993) e Landim (2001).

O dendrograma ilustra as fusões ou partições efetuadas em cada nível sucessivo do processo de agrupamento, no qual o eixo das abscissas representa os indivíduos e o eixo das ordenadas as distâncias obtidas após a utilização de uma metodologia de agrupamento. Os ramos da árvore fornecem a ordem das (n-1) ligações, em que o primeiro nível representa a primeira ligação, o segundo a segunda ligação, e assim sucessivamente, até que todos se juntem.

O algoritmo euclidiano de agrupamento e o método de formação de grupos produzem conjuntos que constituem uma proposição sobre a organização básica e desconhecida dos dados. Entretanto, todo esse procedimento esbarra em uma dificuldade comum, que é a determinação do número ideal de grupos. 
Para auxiliar na decisão do número de grupos, pode-se adotar, segundo Bussab et al. (1990), a técnica hierárquica que consiste em examinar o dendograma em busca de grandes alterações nos níveis de similaridade para as sucessivas fusões. Ela foi adotada neste trabalho.

Na Figura 4 e Tabela 8 encontram-se os países agrupados conforme similaridades de VCR valor adicionado para o ano de 1995. Na figura é possível identificar 06 clusters. O primeiro cluster (vermelho) é formado pelos países especializados em Agricultura e Mineração, sendo eles a Austrália, Rússia, Noruega, África do Sul, Chile e Arábia Saudita.

O segundo cluster (azul) é formado por um grupo de países, em maioria da Europa (neste grupo também se encontra o Brasil e países da Ásia), com uma diversificação industrial exportadora representada principalmente por Produtos Alimentícios, Bebidas e Tabaco, Produtos Químicos e Minerais não metálicos, Agricultura, Silvicultura, Caça e Pesca, Têxteis, Vestuários, Couro e Calçados e Metais básicos e Produtos Metais Fabricados.

Figura 4

Agrupamento VCR Valor Adicionado - países e setores (1995)

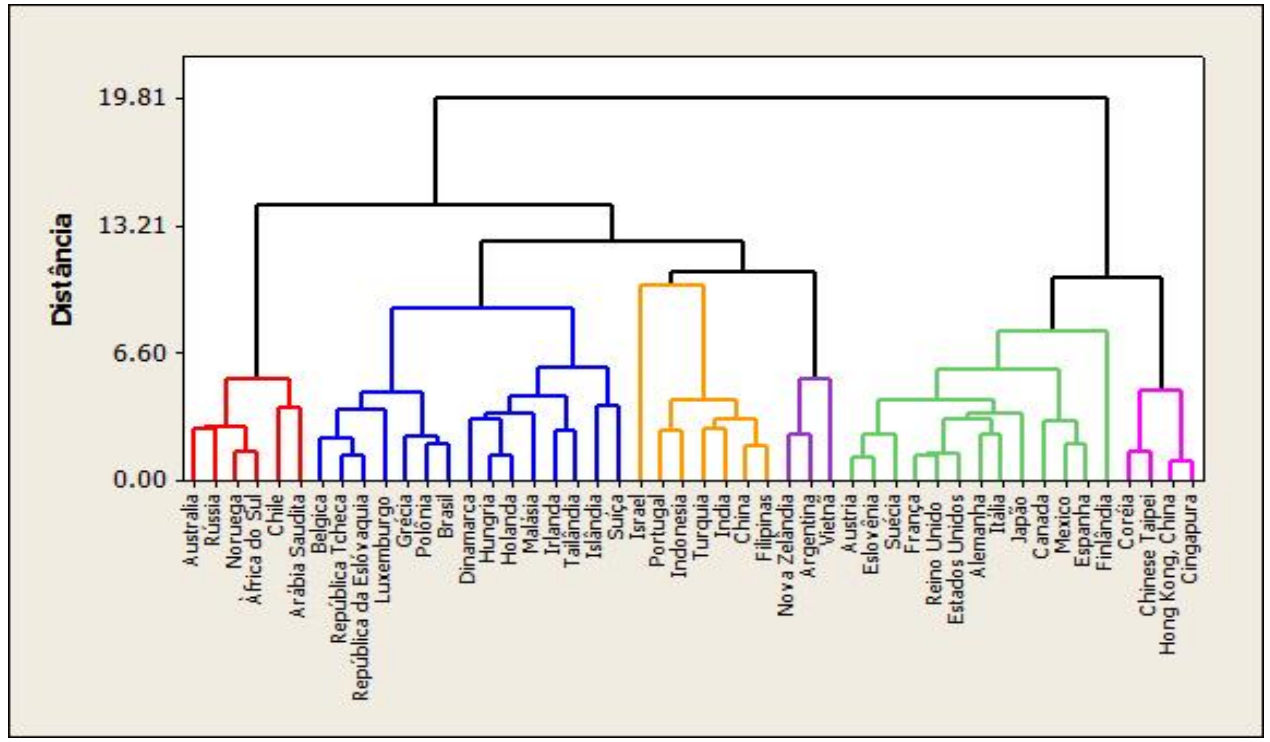

Fonte: Elaboração própria a partir de dados TiVA.

O terceiro cluster (amarelo) é formado por Israel, Portugal, Indonésia, Turquia, Índia, China e Filipinas, países com vantagens comparativas em Têxteis, vestuários, couros e calçados. 
Tabela 8

Vantagens comparativas em valor adicionado dos países (1995)

\begin{tabular}{|c|c|c|c|c|c|c|c|c|c|c|c|}
\hline Cluster 1 & $\begin{array}{l}\text { Agricultura, } \\
\text { sivicultura, } \\
\text { caça e } \\
\text { pesca }\end{array}$ & $\begin{array}{c}\text { Mineração e } \\
\text { Extração }\end{array}$ & $\begin{array}{c}\text { Produtos } \\
\text { alimentícios, } \\
\text { bebidas e } \\
\text { tabaco }\end{array}$ & $\begin{array}{c}\text { Têxteis, } \\
\text { produtos } \\
\text { texteis, } \\
\text { vestuário e } \\
\text { calçados } \\
\end{array}$ & $\begin{array}{c}\text { Madeira, } \\
\text { papel, } \\
\text { produtos do } \\
\text { papel, } \\
\text { impressão e }\end{array}$ & $\begin{array}{c}\text { Produtos } \\
\text { químicos e } \\
\text { minerais não } \\
\text { metálicos }\end{array}$ & \begin{tabular}{|c|} 
Metais \\
básicos e \\
produtos de \\
metais \\
fabricados \\
\end{tabular} & $\begin{array}{c}\text { Máquinas e } \\
\text { equipamentos }\end{array}$ & $\begin{array}{l}\text { Equipamentos } \\
\text { opticos e } \\
\text { elétricos }\end{array}$ & $\begin{array}{l}\text { Equipamentos } \\
\text { de transportes }\end{array}$ & $\begin{array}{c}\text { Indústria } \\
\text { transformação, } \\
\text { nec. } \\
\text { Reciclagem; }\end{array}$ \\
\hline Australia & 2.15 & 3.86 & 2.57 & 0.51 & 0.39 & 0.34 & 2.50 & 0.17 & 0.16 & 0.28 & 0.43 \\
\hline Rússia & 1.55 & 3.71 & 0.31 & 0.20 & 0.96 & 1.05 & 2.67 & 0.74 & 0.12 & 0.32 & 0.09 \\
\hline Noruega & 0.77 & 6.46 & 0.82 & 0.07 & 1.16 & 0.61 & 1.12 & 0.31 & 0.16 & 0.41 & 0.27 \\
\hline África do Sul & 1.27 & 5.79 & 0.58 & 0.27 & 0.62 & 0.63 & 2.03 & 0.20 & 0.07 & 0.27 & 1.45 \\
\hline Chile & 2.54 & 6.60 & 2.29 & 0.20 & 1.87 & 0.21 & 0.27 & 0.07 & 0.01 & 0.09 & 0.20 \\
\hline Arábia Saudita & 0.02 & 10.26 & 0.03 & 0.01 & 0.03 & 1.00 & 0.03 & 0.00 & 0.00 & 0.00 & 0.01 \\
\hline Cluster 2 & $\begin{array}{l}\text { Agricultura, } \\
\text { sivicultura, } \\
\text { cą̧a e } \\
\text { pesca }\end{array}$ & $\begin{array}{c}\text { Mineração e } \\
\text { Extração }\end{array}$ & $\begin{array}{c}\text { Produtos } \\
\text { alimentícios, } \\
\text { bebidas e } \\
\text { tabaco }\end{array}$ & $\begin{array}{c}\text { Têxteis, } \\
\text { produtos } \\
\text { texteis, } \\
\text { vestuário e } \\
\text { calçados }\end{array}$ & $\begin{array}{c}\text { Madeira, } \\
\text { papel, } \\
\text { produtos do } \\
\text { papel, } \\
\text { impressão e } \\
\text { publicação }\end{array}$ & $\begin{array}{c}\begin{array}{c}\text { Produtos } \\
\text { químicos e } \\
\text { minerais não } \\
\text { metálicos }\end{array} \\
\end{array}$ & $\begin{array}{c}\text { Metais } \\
\text { básicos e } \\
\text { produtos de } \\
\text { metais } \\
\text { fabricados }\end{array}$ & $\begin{array}{c}\text { Máquinas e } \\
\text { equipamentos }\end{array}$ & $\begin{array}{l}\text { Equipamentos } \\
\text { ópticos e } \\
\text { elétricos }\end{array}$ & $\begin{array}{l}\text { Equipamentos } \\
\text { de transportes }\end{array}$ & $\begin{array}{c}\text { Indústria } \\
\text { transformação } \\
\text { nec. } \\
\text { Reciclagem; }\end{array}$ \\
\hline Belgica & 0.49 & 0.08 & 1.92 & 1.10 & 0.79 & 1.70 & 1.75 & 0.53 & 0.34 & 1.13 & 1.11 \\
\hline República Tcheca & 1.33 & 0.51 & 0.85 & 1.39 & 1.15 & 1.21 & 2.22 & 0.90 & 0.37 & 0.74 & 1.57 \\
\hline $\begin{array}{l}\text { República da } \\
\text { Eslóvaquia }\end{array}$ & 1.70 & 0.19 & 0.72 & 1.20 & 1.64 & 1.68 & 2.37 & 0.66 & 0.26 & 0.50 & 1.01 \\
\hline Luxemburgo & 1.29 & 0.09 & 1.02 & 1.07 & 0.86 & 1.69 & 4.04 & 0.67 & 0.15 & 0.03 & 0.52 \\
\hline Grécia & 3.33 & 0.41 & 2.67 & 2.61 & 0.47 & 0.97 & 1.81 & 0.24 & 0.18 & 0.46 & 0.65 \\
\hline Polônia & 1.85 & 1.50 & 1.60 & 1.49 & 1.21 & 0.90 & 1.63 & 0.44 & 0.24 & 0.72 & 2.03 \\
\hline Brasil & 0.79 & 1.15 & 3.43 & 1.07 & 1.27 & 0.78 & 2.04 & 0.49 & 0.22 & 0.63 & 0.47 \\
\hline Dinamarca & 1.47 & 0.34 & 3.82 & 0.55 & 0.86 & 1.04 & 0.68 & 1.43 & 0.50 & 0.27 & 2.44 \\
\hline Hungria & 3.75 & 0.06 & 2.42 & 1.09 & 0.66 & 1.29 & 1.28 & 0.55 & 0.59 & 0.56 & 0.49 \\
\hline Holanda & 2.93 & 0.76 & 3.12 & 0.28 & 0.95 & 1.54 & 0.90 & 0.50 & 0.46 & 0.40 & 0.60 \\
\hline Malásia & 4.90 & 1.32 & 0.77 & 0.40 & 0.97 & 1.32 & 0.27 & 0.94 & 1.19 & 0.07 & 0.25 \\
\hline Irlanda & 0.73 & 0.14 & 3.57 & 0.47 & 1.97 & 1.43 & 0.33 & 0.36 & 1.32 & 0.14 & 0.27 \\
\hline Tailândia & 0.69 & 0.06 & 2.76 & 2.07 & 0.41 & 0.79 & 0.52 & 0.17 & 1.88 & 0.20 & 2.25 \\
\hline Islândia & 0.94 & 0.08 & 1.15 & 0.19 & 1.43 & 2.74 & 0.27 & 0.21 & 1.49 & 0.09 & 0.20 \\
\hline Suiça & 0.20 & 0.03 & 0.75 & 0.25 & 0.83 & 1.93 & 0.82 & 1.90 & 1.35 & 0.08 & 1.48 \\
\hline Cluster 3 & $\begin{array}{c}\text { Agricultura, } \\
\text { sivicultura, } \\
\text { caça e } \\
\text { pesca }\end{array}$ & $\begin{array}{c}\text { Mineração e } \\
\text { Extração }\end{array}$ & \begin{tabular}{|c|} 
Produtos \\
alimentícios, \\
bebidas e \\
tabaco
\end{tabular} & $\begin{array}{c}\text { Têxteis, } \\
\text { produtos } \\
\text { texteis, } \\
\text { vestuário e } \\
\text { calçados }\end{array}$ & $\begin{array}{c}\text { Madeira, } \\
\text { papel, } \\
\text { produtos do } \\
\text { papel, } \\
\text { impressão e } \\
\text { publicação }\end{array}$ & $\begin{array}{c}\begin{array}{c}\text { Produtos } \\
\text { químicos e } \\
\text { minerais năo } \\
\text { metálicos }\end{array} \\
\end{array}$ & $\begin{array}{c}\text { Metais } \\
\text { básicos e } \\
\text { produtos de } \\
\text { metais } \\
\text { fabricados }\end{array}$ & $\begin{array}{c}\text { Máquinas e } \\
\text { equipamentos }\end{array}$ & $\begin{array}{l}\text { Equipamentos } \\
\text { opticos e } \\
\text { elétricos }\end{array}$ & $\begin{array}{l}\text { Equipamentos } \\
\text { de transportes }\end{array}$ & $\begin{array}{c}\text { Indústria } \\
\text { transformação, } \\
\text { nec. } \\
\text { Reciclagem; }\end{array}$ \\
\hline Israel & 0.97 & 0.16 & 0.50 & 0.59 & 0.11 & 0.78 & 0.37 & 0.35 & 0.96 & 0.20 & 17.95 \\
\hline Portugal & 0.47 & 0.27 & 0.90 & 5.10 & 2.16 & 0.77 & 0.42 & 0.31 & 0.64 & 0.76 & 0.75 \\
\hline Indonesia & 0.60 & 3.09 & 1.78 & 2.82 & 2.59 & 0.88 & 0.41 & 0.12 & 0.19 & 0.12 & 0.62 \\
\hline Turquia & 2.75 & 0.24 & 1.40 & 6.03 & 0.16 & 0.65 & 1.50 & 0.24 & 0.22 & 0.31 & 0.74 \\
\hline India & 2.98 & 0.36 & 0.98 & 4.55 & 0.68 & 1.39 & 0.41 & 0.24 & 0.17 & 0.18 & 3.69 \\
\hline China & 0.92 & 0.30 & 0.89 & 4.37 & 0.19 & 0.72 & 0.98 & 0.63 & 1.00 & 0.23 & 3.73 \\
\hline Filipinas & 1.56 & 1.48 & 1.41 & 3.43 & 0.71 & 0.36 & 1.11 & 0.14 & 1.20 & 0.04 & 2.18 \\
\hline Cluster 4 & $\begin{array}{c}\text { Agricultura, } \\
\text { sivicultura, } \\
\text { caça e } \\
\text { pesca }\end{array}$ & $\begin{array}{l}\text { Mineração e } \\
\text { Extração }\end{array}$ & $\begin{array}{c}\text { Produtos } \\
\text { alimentícios, } \\
\text { bebidas e } \\
\text { tabaco }\end{array}$ & $\begin{array}{c}\text { Têxteis, } \\
\text { produtos } \\
\text { texteis, } \\
\text { vestuário e } \\
\text { calçados }\end{array}$ & $\begin{array}{c}\text { Madeira, } \\
\text { papel, } \\
\text { produtos do } \\
\text { papel, } \\
\text { impressão e } \\
\text { publicação }\end{array}$ & $\begin{array}{c}\text { Produtos } \\
\text { químicos e } \\
\text { minerais naóo } \\
\text { metálicos }\end{array}$ & $\begin{array}{c}\text { Metais } \\
\text { básicos e } \\
\text { produtos de } \\
\text { metais } \\
\text { fabricados }\end{array}$ & $\begin{array}{c}\text { Máquinas e } \\
\text { equipamentos }\end{array}$ & $\begin{array}{l}\text { Equipamentos } \\
\text { opticos e } \\
\text { elétricos }\end{array}$ & $\begin{array}{l}\text { Equipamentos } \\
\text { de transportes }\end{array}$ & $\begin{array}{c}\text { Indústria } \\
\text { transformação, } \\
\text { nec. } \\
\text { Reciclagem; }\end{array}$ \\
\hline Nova Zelândia & 4.30 & 0.40 & 5.85 & 0.77 & 2.07 & 0.44 & 0.76 & 0.24 & 0.17 & 0.10 & 0.43 \\
\hline Argentina & 3.79 & 1.06 & 4.92 & 1.22 & 0.33 & 0.71 & 0.63 & 0.21 & 0.09 & 0.86 & 0.26 \\
\hline Vietnã & 7.86 & 3.69 & 2.11 & 2.66 & 0.45 & 0.04 & 0.05 & 0.08 & 0.07 & 0.02 & 0.33 \\
\hline Cluster 5 & $\begin{array}{c}\text { Agricultura, } \\
\text { sivicultura, } \\
\text { caça e } \\
\text { pesca }\end{array}$ & $\begin{array}{l}\text { Mineração e } \\
\text { Extração }\end{array}$ & $\begin{array}{c}\text { Produtos } \\
\text { alimentícios, } \\
\text { bebidas e } \\
\text { tabaco }\end{array}$ & $\begin{array}{c}\text { Têxteis, } \\
\text { produtos } \\
\text { texteis, } \\
\text { vestuário e } \\
\text { calçados }\end{array}$ & $\begin{array}{c}\text { Madeira, } \\
\text { papel, } \\
\text { produtos do } \\
\text { papel, } \\
\text { impressão e } \\
\text { publicação }\end{array}$ & $\begin{array}{c}\text { Produtos } \\
\text { químicos e } \\
\text { minerais naóo } \\
\text { metálicos }\end{array}$ & $\begin{array}{c}\text { Metais } \\
\text { básicos e } \\
\text { produtos de } \\
\text { metais } \\
\text { fabricados }\end{array}$ & $\begin{array}{c}\text { Máquinas e } \\
\text { equipamentos }\end{array}$ & $\begin{array}{c}\text { Equipamentos } \\
\text { ópticos e } \\
\text { elétricos }\end{array}$ & $\begin{array}{l}\text { Equipamentos } \\
\text { de transportes }\end{array}$ & $\begin{array}{c}\text { Indústria } \\
\text { transformação, } \\
\text { nec. } \\
\text { Reciclagem; }\end{array}$ \\
\hline Austria & 0.33 & 0.07 & 0.54 & 1.09 & 2.26 & 1.05 & 1.64 & 1.40 & 0.77 & 0.80 & 1.45 \\
\hline Eslovênia & 0.40 & 0.01 & 0.66 & 1.94 & 1.68 & 1.19 & 1.21 & 1.17 & 0.68 & 0.83 & 2.26 \\
\hline Suécia & 0.33 & 0.15 & 0.35 & 0.22 & 3.51 & 0.84 & 1.28 & 1.36 & 0.86 & 1.27 & 0.81 \\
\hline França & 1.65 & 0.05 & 1.39 & 0.70 & 0.77 & 1.30 & 1.03 & 0.99 & 0.79 & 1.37 & 0.92 \\
\hline Reino Unido & 0.39 & 1.02 & 0.97 & 0.63 & 0.74 & 1.36 & 0.86 & 1.09 & 1.06 & 1.02 & 0.83 \\
\hline Estados Unidos & 1.44 & 0.44 & 1.01 & 0.43 & 1.19 & 0.98 & 0.66 & 1.18 & 1.44 & 1.06 & 0.44 \\
\hline Alemanha & 0.33 & 0.07 & 0.68 & 0.41 & 0.83 & 1.27 & 1.22 & 1.81 & 0.75 & 1.66 & 0.62 \\
\hline Itália & 0.63 & 0.05 & 0.79 & 2.42 & 0.54 & 1.04 & 1.25 & 1.97 & 0.50 & 0.74 & 2.23 \\
\hline Japão & 0.03 & 0.01 & 0.07 & 0.24 & 0.29 & 0.66 & 0.78 & 1.48 & 2.12 & 1.95 & 0.43 \\
\hline Canada & 1.05 & 1.77 & 0.59 & 0.26 & 3.02 & 0.65 & 1.14 & 0.35 & 0.42 & 1.86 & 0.93 \\
\hline Mexico & 1.32 & 1.40 & 0.58 & 1.09 & 0.33 & 0.85 & 1.05 & 0.20 & 1.07 & 1.65 & 2.01 \\
\hline Espanha & 2.23 & 0.08 & 1.11 & 0.94 & 0.73 & 1.22 & 1.11 & 0.67 & 0.49 & 1.98 & 0.81 \\
\hline Finlândia & 0.26 & 0.05 & 0.40 & 0.27 & 6.50 & 0.55 & 1.13 & 1.44 & 0.83 & 0.34 & 0.70 \\
\hline Cluster 6 & $\begin{array}{c}\text { Agricultura, } \\
\text { sivicultura, } \\
\text { caça e } \\
\text { pesca }\end{array}$ & $\begin{array}{c}\text { Mineração e } \\
\text { Extração }\end{array}$ & $\begin{array}{c}\text { Produtos } \\
\text { alimentícios, } \\
\text { bebidas e } \\
\text { tabaco }\end{array}$ & $\begin{array}{c}\text { Têxteis, } \\
\text { produtos } \\
\text { texteis, } \\
\text { vestuário e } \\
\text { calçados }\end{array}$ & $\begin{array}{c}\text { Madeira, } \\
\text { papel, } \\
\text { produtos do } \\
\text { papel, } \\
\text { impressão e } \\
\text { publicação }\end{array}$ & $\begin{array}{c}\text { Produtos } \\
\text { químicos e } \\
\text { minerais não } \\
\text { metálicos } \\
\end{array}$ & $\begin{array}{c}\text { Metais } \\
\text { básicos e } \\
\text { produtos de } \\
\text { metais } \\
\text { fabricados }\end{array}$ & $\begin{array}{c}\text { Máquinas e } \\
\text { equipamentos }\end{array}$ & $\begin{array}{c}\text { Equipamentos } \\
\text { óticos e } \\
\text { elétricos }\end{array}$ & $\begin{array}{l}\text { Equipamentos } \\
\text { de transportes }\end{array}$ & $\begin{array}{c}\text { Indústria } \\
\text { transformação, } \\
\text { nec. } \\
\text { Reciclagem; }\end{array}$ \\
\hline Coréia & 0.35 & 0.01 & 0.31 & 2.67 & 0.23 & 0.82 & 0.96 & 0.63 & 1.85 & 1.09 & 0.80 \\
\hline Chinese Taipei & 0.52 & 0.01 & 0.45 & 1.99 & 0.43 & 0.95 & 1.26 & 0.77 & 1.93 & 0.43 & 1.71 \\
\hline $\begin{array}{l}\text { Hong Kong, } \\
\text { China }\end{array}$ & 0.27 & 0.10 & 0.37 & 0.29 & 0.42 & 1.19 & 0.70 & 0.42 & 3.10 & 0.34 & 0.58 \\
\hline Singapura & 0.06 & 0.01 & 0.22 & 0.18 & 0.22 & 1.19 & 0.40 & 0.30 & 3.70 & 0.21 & 0.36 \\
\hline
\end{tabular}

Fonte: Elaboração própria a partir de dados da OCDE/TiVA. 
O quarto cluster (lilás) apresenta as vantagens comparativas da Nova Zelândia, Argentina e Vietnã em Agricultura, Silvicultura, Caça e Pesca e Produtos Alimentícios, Bebidas e Tabaco. O quinto cluster (verde) é formado pela maioria dos países da União Europeia: Áustria, Eslovênia, Suécia, França, Reino Unido, Estados Unidos, Alemanha, Itália, Japão, Canadá, México, Espanha e Finlândia e as vantagens comparativas em Metais Básicos e Produtos de Metais Fabricados, Máquinas e Equipamentos, Equipamentos de Transportes e Produtos Químicos e Minerais Não Metálicos.

A constituição do último cluster se justifica principalmente pelas vantagens comparativas em Equipamentos Elétricos e Ópticos, sendo reunidos os países Coréia, Taipé Chinesa, Hong Kong e Cingapura.

Se sugerirmos um novo corte nos agrupamentos, algo entre 13.21 e 19.81 (vide Figura 05, eixo das distâncias), temos a configuração de dois blocos de vantagens comparativas.

Na Figura 04 um maior bloco de países realça vantagens comparativas em Agricultura, Mineração, Produtos Alimentícios, Têxteis, Metais Básicos e Produtos Químicos. Notadamente, coexistem neste grupo, países com vantagens comparativas em setores baseados em recursos naturais, mas também setores propensos à lógica de integração produtiva em cadeias.

Ainda na figura 04, tem-se um menor bloco formado por países da União Europeia (Áustria, Eslovênia, Suécia, França, Reino Unido, Alemanha, Itália, Espanha, Finlândia), Ásia Pacífico (Coréia, Taipé Chinesa, Hong Kong, Cingapura e Japão) e América (Estados Unidos, Canadá, México) - bloco composto por países que possuem vantagens comparativas em setores tradicionais da lógica de produção em rede (Equipamentos de Transporte, Equipamentos Ópticos e Eletrônicos, Máquinas e Equipamentos e Produtos Químicos).

De posse desta informação e revisitando as Tabelas 2, 3 e 4, tem-se que o referido bloco é formado por países da União Europeia, Ásia e América do Norte, que já em 1995 apresentavam posições upstream na produção em rede, comandando regionalmente a dinâmica das cadeias.

O desdobramento desta constatação é que no ano de 2009 (Figura 5) encontra-se mais evidente a acomodação competitiva dos países no âmbito dos fluxos de comércio em bens finais e comércio em valor adicionado. Vejamos.

A Figura 5 ilustra, para o ano de 2009, a formação de 06 clusters e, em conjunto com a Tabela 9, apresenta os padrões das vantagens comparativas dos países. A similaridade das vantagens comparativas em Mineração e Extração constitui o primeiro grupo formado por Austrália, África do Sul, Rússia, Chile, Noruega e Arábia Saudita (vermelho). O segundo cluster (lilás) é formado pela Nova 
Zelândia, Argentina, Brasil e Vietnã cujas vantagens comparativas, principalmente em Agricultura, Silvicultura, Caça e Pesca e Produtos Alimentícios, Bebidas e Fumo são condicionantes da formação do grupo (Tabela 9).

Figura 5

Agrupamento VCR Valor Adicionado - países e setores (2009)

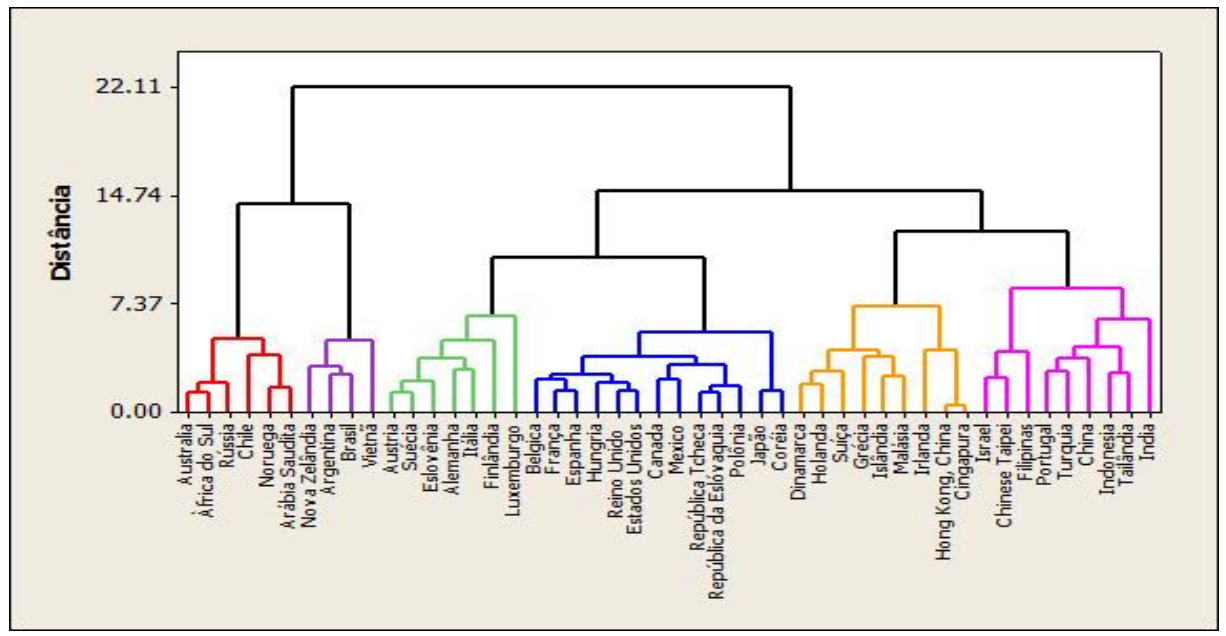

Fonte: Elaboração Própria a partir de dados TiVA.

O terceiro cluster (verde) é formado por Áustria, Suécia, Eslovênia, Alemanha, Itália, Finlândia e Luxemburgo. Ele representa o agrupamento das vantagens comparativas em Metais básicos e produtos não metálicos e Máquinas e Equipamentos e para boa parte dos países que compõem o grupo, a especialização também acontece em Madeira, papel e produtos do papel e Produtos Químicos e Minerais não metálicos.

O quarto cluster (azul) é formado pelas vantagens comparativas em Equipamentos de Transportes de países como Bélgica, França, Espanha, Hungria, Reino Unido, Estados Unidos, Canadá, México, República Tcheca, República Eslováquia, Polônia, Japão e Coréia. Uma parte destes países também apresenta especialização em Madeira, Papel e Produtos de papel, Produtos Químicos e Minerais não metálicos e Metais Básicos.

O quinto cluster (amarelo) é constituído por Dinamarca, Holanda, Suíça, Grécia, Islândia, Malásia, Irlanda, Hong Kong, China e Singapura. A similaridade em termos de vantagens comparativas se dá em Produtos Químicos e Minerais não metálicos. Porém, uma parte dos países também apresenta especialização em Produtos Alimentícios, Bebidas e Fumo, Madeira, Papel e Produtos do Papel, Equipamentos Elétricos e Ópticos e Máquinas e Equipamentos. 
Tabela 9

Vantagens comparativas em valor adicionado (2009)

\begin{tabular}{|c|c|c|c|c|c|c|c|c|c|c|c|}
\hline Cluster 1 & $\begin{array}{l}\text { Agricultura, caca, } \\
\text { sivicultura e pesca }\end{array}$ & $\begin{array}{c}\text { Mineracăāo e } \\
\text { Extraçāo }\end{array}$ & $\begin{array}{c}\text { Produtos } \\
\text { alimentícios, } \\
\text { bebidas e } \\
\text { fumo }\end{array}$ & $\begin{array}{c}\text { Texteis, } \\
\text { vestuários, } \\
\text { couro e } \\
\text { calçados }\end{array}$ & $\begin{array}{c}\text { Madeira, } \\
\text { papel, } \\
\text { produtos de } \\
\text { papel, } \\
\text { impressāoe } \\
\text { publicaçāo }\end{array}$ & $\begin{array}{c}\text { Produtos } \\
\text { Químicos e } \\
\text { minerais } \\
\text { não } \\
\text { metálicos } \\
\end{array}$ & $\begin{array}{c}\text { Metais } \\
\text { básicos e } \\
\text { produtos } \\
\text { metálicos }\end{array}$ & $\begin{array}{c}\text { Máquinas e } \\
\text { Equipamentos }\end{array}$ & $\begin{array}{c}\text { Equipamento } \\
\text { Elétrico e } \\
\text { Óptico }\end{array}$ & $\begin{array}{l}\text { Equipamentos } \\
\text { de Transporte }\end{array}$ & $\begin{array}{c}\text { Indústria } \\
\text { transformação } \\
\text {, nec. } \\
\text { Reciclagem; }\end{array}$ \\
\hline Australlia & 1.62 & 3.27 & 1.61 & 0.16 & 0.34 & 0.37 & 1.95 & 0.33 & 0.12 & 0.22 & 0.25 \\
\hline África do Sul & 1.74 & 3.16 & 0.72 & 0.17 & 0.82 & 0.61 & 1.83 & 0.00 & 0.07 & 0.54 & 0.81 \\
\hline Rússia & 1.02 & 3.05 & 0.24 & 0.03 & 0.84 & 1.21 & 1.76 & 0.55 & 0.11 & 0.13 & 0.05 \\
\hline Chile & 2.49 & 3.77 & 1.69 & 0.10 & 2.62 & 0.30 & 0.26 & 0.11 & 0.01 & 0.10 & 0.11 \\
\hline Noruega & 0.53 & 4.54 & 0.57 & 0.02 & 0.38 & 0.47 & 0.60 & 0.58 & 0.13 & 0.15 & 0.12 \\
\hline Arábia Saudita & 0.02 & 5.40 & 0.05 & 0.01 & 0.04 & 0.89 & 0.03 & 0.00 & 0.00 & 0.00 & 0.00 \\
\hline Cluster 2 & $\begin{array}{l}\text { Agricultura, caca, } \\
\text { sivicultura e pesca }\end{array}$ & $\begin{array}{c}\text { Mineraçãoe } \\
\text { Exraçāo }\end{array}$ & $\begin{array}{c}\text { Produtos } \\
\text { alimentícios, } \\
\text { bebidas e } \\
\text { fumo }\end{array}$ & $\begin{array}{c}\text { Texteis, } \\
\text { vestuários, } \\
\text { couro e } \\
\text { calçados }\end{array}$ & $\begin{array}{c}\text { Madeira, } \\
\text { papel, } \\
\text { produtos de } \\
\text { papel, } \\
\text { impressão e } \\
\text { publicacạāo } \\
\end{array}$ & $\begin{array}{c}\text { Produtos } \\
\text { Químicos e } \\
\text { minerais } \\
\text { nao } \\
\text { metálicos } \\
\\
\end{array}$ & $\begin{array}{c}\text { Metais } \\
\text { básicos e } \\
\text { produtos } \\
\text { metálicos }\end{array}$ & $\begin{array}{c}\text { Máquinas e } \\
\text { Equipamentos }\end{array}$ & $\begin{array}{c}\text { Equipamento } \\
\text { Elétrico e } \\
\text { Óptico }\end{array}$ & $\begin{array}{l}\text { Equipamentos } \\
\text { de Transporte }\end{array}$ & $\begin{array}{c}\text { Indústria } \\
\text { transformação } \\
\text {,nec. } \\
\text { Reciclagem; }\end{array}$ \\
\hline Nova Zelândia & 4.72 & 0.28 & 5.86 & 0.86 & 2.86 & 0.43 & 0.84 & 0.32 & 0.22 & 0.13 & 0.38 \\
\hline Argentina & 4.63 & 0.50 & 5.36 & 1.42 & 0.53 & 0.68 & 0.62 & 0.23 & 0.10 & 0.81 & 0.22 \\
\hline Brasil & 4.36 & 0.89 & 3.09 & 0.45 & 1.13 & 0.76 & 1.40 & 0.47 & 0.25 & 0.87 & 0.21 \\
\hline Vietnā & 7.68 & 2.05 & 2.60 & 2.48 & 0.75 & 0.09 & 0.08 & 0.10 & 0.11 & 0.05 & 0.33 \\
\hline Cluster 3 & $\begin{array}{l}\text { Agricultura, caça, } \\
\text { sivicultura e pesca }\end{array}$ & $\begin{array}{l}\text { Mineraçāoe e } \\
\text { Extraçāo }\end{array}$ & $\begin{array}{l}\text { Produtos } \\
\text { alimentícios, } \\
\text { bebidas e } \\
\text { fumo }\end{array}$ & $\begin{array}{c}\text { Texteis, } \\
\text { vestuários, } \\
\text { couro e } \\
\text { calcados }\end{array}$ & $\begin{array}{c}\text { Madeira, } \\
\text { papel, } \\
\text { produtos de } \\
\text { papel, } \\
\text { impressão } \\
\text { publicaçãa }\end{array}$ & $\begin{array}{c}\text { Produtos } \\
\text { Químicos e } \\
\text { minerais } \\
\text { não } \\
\text { metálicos } \\
\end{array}$ & $\begin{array}{l}\text { Metais } \\
\text { básicos e } \\
\text { produtos } \\
\text { metálicos }\end{array}$ & $\begin{array}{c}\text { Máquinas e } \\
\text { Equipamentos }\end{array}$ & $\begin{array}{c}\text { Equipamento } \\
\text { Elétrico e } \\
\text { Óptico }\end{array}$ & $\begin{array}{l}\text { Equipamentos } \\
\text { de Transporte }\end{array}$ & $\begin{array}{c}\text { Indústria } \\
\text { transformaçāo } \\
\text {, nec. } \\
\text { Reciclagem, }\end{array}$ \\
\hline Austria & 0.36 & 0.03 & 1.40 & 0.52 & 2.88 & 0.87 & 1.86 & 1.88 & 0.66 & 1.06 & 1.28 \\
\hline Suécia & 0.29 & 0.18 & 0.43 & 0.16 & 3.52 & 0.96 & 1.63 & 1.92 & 0.83 & 1.29 & 0.94 \\
\hline Eslovênia & 0.80 & 0.02 & 0.76 & 0.81 & 1.90 & 1.42 & 1.70 & 1.51 & 0.75 & 1.10 & 0.95 \\
\hline Alemanha & 0.27 & 0.02 & 0.75 & 0.21 & 1.15 & 1.12 & 1.27 & 2.36 & 0.86 & 1.91 & 0.75 \\
\hline Itália & 0.55 & 0.03 & 1.14 & 2.15 & 0.71 & 1.01 & 1.38 & 2.16 & 0.62 & 0.99 & 1.74 \\
\hline Finlândia & 0.26 & 0.02 & 0.35 & 0.20 & 5.09 & 0.90 & 1.11 & 1.99 & 1.65 & 0.42 & 0.28 \\
\hline Luxemburgo & 0.98 & 0.05 & 1.28 & 1.27 & 1.96 & 1.34 & 4.07 & 0.81 & 0.35 & 0.07 & 0.29 \\
\hline Clusrer 4 & $\begin{array}{l}\text { Agricultura, caça, } \\
\text { sivicultura e pesca }\end{array}$ & $\begin{array}{c}\text { Mineraçāo e } \\
\text { Extraçāo }\end{array}$ & $\begin{array}{l}\text { Produtos } \\
\text { alimentícios, } \\
\text { bebidas e } \\
\text { fumo }\end{array}$ & $\begin{array}{c}\text { Texteis, } \\
\text { vestuários, } \\
\text { couro e } \\
\text { calçados }\end{array}$ & $\begin{array}{c}\text { Madeira, } \\
\text { papel, } \\
\text { produtos de } \\
\text { papel, } \\
\text { impressão e } \\
\text { publicacạāo }\end{array}$ & $\begin{array}{c}\text { Produtos } \\
\text { Químicos e } \\
\text { minerais } \\
\text { nao } \\
\text { metálicos } \\
\\
\end{array}$ & $\begin{array}{l}\text { Metais } \\
\text { básicos e } \\
\text { produtos } \\
\text { metálicos }\end{array}$ & $\begin{array}{c}\text { Máquinas e } \\
\text { Equipamentos }\end{array}$ & $\begin{array}{c}\text { Equipamento } \\
\text { Elétrico e } \\
\text { Óptico }\end{array}$ & $\begin{array}{l}\text { Equipamentos } \\
\text { de Transporte }\end{array}$ & $\begin{array}{c}\text { Indústria } \\
\text { transformaçāo } \\
\text {, nec. } \\
\text { Reciclagem, }\end{array}$ \\
\hline Belgica & 0.75 & 0.03 & 1.87 & 0.81 & 0.71 & 2.17 & 1.43 & 0.70 & 0.42 & 1.09 & 0.82 \\
\hline França & 1.82 & 0.03 & 1.84 & 0.55 & 0.95 & 1.36 & 1.01 & 1.27 & 0.60 & 1.67 & 0.89 \\
\hline Espanha & 2.18 & 0.04 & 1.62 & 1.33 & 0.81 & 1.36 & 1.17 & 0.71 & 0.51 & 1.89 & 0.50 \\
\hline Hungria & 2.00 & 0.02 & 0.98 & 0.36 & 0.71 & 1.19 & 0.77 & 0.81 & 1.95 & 1.44 & 0.42 \\
\hline Reino Unido & 0.28 & 0.56 & 1.16 & 0.58 & 0.99 & 1.61 & 0.88 & 0.95 & 0.87 & 1.37 & 0.92 \\
\hline Estados Unidos & 1.45 & 0.13 & 0.99 & 0.22 & 1.68 & 1.32 & 0.81 & 1.15 & 1.23 & 1.38 & 1.23 \\
\hline Canada & 1.78 & 2.14 & 0.80 & 0.18 & 1.73 & 0.78 & 0.99 & 0.44 & 0.33 & 1.21 & 0.84 \\
\hline Mexico & 1.11 & 1.17 & 0.83 & 0.64 & 0.30 & 0.72 & 1.14 & 0.38 & 1.16 & 1.88 & 1.09 \\
\hline República Tcheca & 0.85 & 0.12 & 0.78 & 0.62 & 1.46 & 0.99 & 1.51 & 1.20 & 0.86 & 2.00 & 1.35 \\
\hline $\begin{array}{l}\text { República da } \\
\text { Eslóvaquia }\end{array}$ & 1.50 & 0.04 & 0.98 & 0.68 & 1.76 & 0.86 & 1.94 & 0.75 & 1.13 & 1.60 & 1.06 \\
\hline Polônia & 0.90 & 0.20 & 1.77 & 0.94 & 1.43 & 0.98 & 1.22 & 0.91 & 0.70 & 1.60 & 1.98 \\
\hline Japão & 0.04 & 0.00 & 0.12 & 0.17 & 0.18 & 0.85 & 1.28 & 1.51 & 1.84 & 2.40 & 1.12 \\
\hline Coréia & 0.08 & 0.00 & 0.26 & 0.75 & 0.28 & 0.75 & 1.13 & 1.08 & 2.23 & 2.30 & 0.29 \\
\hline Cluster 5 & $\begin{array}{l}\text { Agricultura, caça, } \\
\text { sivicultura e pesca }\end{array}$ & $\begin{array}{l}\text { Mineraçāo e } \\
\text { Extraçăo }\end{array}$ & $\begin{array}{l}\text { Produtos } \\
\text { alimentícios, } \\
\text { bebidas e } \\
\text { fumo }\end{array}$ & $\begin{array}{c}\text { Texteis, } \\
\text { vestuários, } \\
\text { couro e } \\
\text { calçados }\end{array}$ & $\begin{array}{c}\text { Madeira, } \\
\text { papel, } \\
\text { produtos de } \\
\text { papel, } \\
\text { impressāa e } \\
\text { publicacạāo } \\
\end{array}$ & $\begin{array}{c}\text { Produtos } \\
\text { Químicos } \mathrm{e} \\
\text { minerais } \\
\text { não } \\
\text { metálicos } \\
\end{array}$ & $\begin{array}{c}\text { Metais } \\
\text { básicos e } \\
\text { produtos } \\
\text { metálicos }\end{array}$ & $\begin{array}{c}\text { Máquinas e } \\
\text { Equipamentos }\end{array}$ & $\begin{array}{c}\text { Equipamento } \\
\text { Elétrico e } \\
\text { Óptico }\end{array}$ & $\begin{array}{l}\text { Equipamentos } \\
\text { de Transporte }\end{array}$ & $\begin{array}{c}\text { Indústria } \\
\text { transformação } \\
\text {, nec. } \\
\text { Reciclagem; }\end{array}$ \\
\hline Dinamarca & 1.15 & 0.41 & 3.06 & 0.32 & 0.62 & 1.38 & 0.62 & 1.64 & 0.95 & 0.24 & 1.25 \\
\hline Holanda & 2.67 & 0.80 & 2.78 & 0.21 & 0.87 & 1.52 & 0.86 & 1.03 & 0.31 & 0.50 & 0.68 \\
\hline Suiça & 0.17 & 0.00 & 1.26 & 0.23 & 1.30 & 1.67 & 1.00 & 1.85 & 1.66 & 0.17 & 0.89 \\
\hline Grécia & 3.16 & 0.07 & 1.96 & 1.41 & 0.58 & 2.08 & 2.01 & 0.39 & 0.37 & 0.11 & 0.34 \\
\hline Islândia & 2.33 & 0.22 & 2.10 & 0.26 & 2.03 & 2.04 & 0.41 & 0.18 & 1.40 & 0.13 & 0.38 \\
\hline Malásia & 3.41 & 1.28 & 0.72 & 0.42 & 1.32 & 1.30 & 0.28 & 1.01 & 1.32 & 0.08 & 0.16 \\
\hline Irlanda & 0.25 & 0.00 & 2.76 & 0.03 & 0.38 & 3.63 & 0.17 & 0.36 & 0.76 & 0.02 & 0.00 \\
\hline Hong Kong, China & 0.18 & 0.00 & 0.13 & 0.05 & 0.13 & 2.55 & 0.32 & 0.87 & 2.35 & 0.60 & 0.21 \\
\hline Singapura & 0.03 & 0.00 & 0.28 & 0.06 & 0.34 & 2.56 & 0.42 & 0.97 & 2.07 & 0.66 & 0.30 \\
\hline Cluster 6 & $\begin{array}{l}\text { Agricultura, caça, } \\
\text { sivicultura e pesca }\end{array}$ & $\begin{array}{c}\text { Mineraçāo e } \\
\text { Extração }\end{array}$ & $\begin{array}{l}\text { Produtos } \\
\text { alimentícios, } \\
\text { bebidas e } \\
\text { fumo }\end{array}$ & $\begin{array}{c}\text { Texteis, } \\
\text { vestuários, } \\
\text { couro e } \\
\text { calçados }\end{array}$ & $\begin{array}{c}\text { Madeira, } \\
\text { papel, } \\
\text { produtos de } \\
\text { papel, } \\
\text { impressão } \\
\text { publicaçāo } \\
\end{array}$ & $\begin{array}{c}\text { Produtus } \\
\text { Químicos e } \\
\text { minerais } \\
\text { nāo } \\
\text { metálicos } \\
\end{array}$ & $\begin{array}{l}\text { Metais } \\
\text { básicos e } \\
\text { produtos } \\
\text { metálicos }\end{array}$ & $\begin{array}{c}\text { Máquinas e } \\
\text { Equipamentos }\end{array}$ & $\begin{array}{c}\text { Equipamento } \\
\text { Elétrico e } \\
\text { Óptico }\end{array}$ & $\begin{array}{l}\text { Equipamentos } \\
\text { de Transporte }\end{array}$ & $\begin{array}{c}\text { Indústria } \\
\text { transformação } \\
\text {,nec. } \\
\text { Reciclagem; }\end{array}$ \\
\hline Israel & 1.82 & 0.16 & 0.33 & 0.68 & 0.29 & 1.39 & 0.64 & 0.42 & 2.36 & 0.75 & 1.83 \\
\hline Chinese Taipei & 0.21 & 0.00 & 0.14 & 0.74 & 0.21 & 1.11 & 1.22 & 0.62 & 3.36 & 0.43 & 0.60 \\
\hline Filipinas & 0.68 & 0.13 & 0.23 & 1.21 & 0.16 & 0.08 & 0.09 & 0.19 & 5.10 & 0.36 & 0.14 \\
\hline Portugal & 0.89 & 0.22 & 1.29 & 2.74 & 2.27 & 1.10 & 1.22 & 0.66 & 0.67 & 1.02 & 0.71 \\
\hline Turquia & 1.68 & 0.13 & 0.95 & 3.57 & 0.37 & 0.77 & 2.20 & 0.89 & 0.36 & 1.41 & 0.76 \\
\hline China & 0.30 & 0.05 & 0.42 & 3.59 & 0.57 & 0.59 & 1.02 & 0.94 & 2.14 & 0.41 & 2.14 \\
\hline Indonesia & 0.76 & 1.61 & 2.47 & 1.43 & 1.22 & 1.17 & 0.66 & 0.39 & 0.48 & 0.29 & 0.81 \\
\hline Tailândia & 0.74 & 0.06 & 3.08 & 2.40 & 0.53 & 0.86 & 0.62 & 0.23 & 1.81 & 0.33 & 1.85 \\
\hline India & 1.80 & 0.49 & 0.72 & 2.23 & 0.38 & 0.86 & 1.01 & 0.45 & 1.05 & 0.56 & 5.03 \\
\hline
\end{tabular}

Fonte: Elaboração própria a partir de dados da OCDE/TiVA. 
Se sugerirmos uma mudança no corte dos agrupamentos (vide figura 5) para algo entre 14.74 e 22.11 (eixo da distância) é possível perceber a constituição de um grande bloco de países, nos quais estão inseridos os países da União Europeia, Ásia e América do Norte, que em grande parte, determinavam, em 1995, a dinâmica regional da integração produtiva (vide Figura 4).

Todavia, apresenta-se também neste bloco uma gama de países (Bélgica, Hungria, República Tcheca, República da Eslováquia, Polônia, Índia, Tailândia, Indonésia, China, Turquia, Portugal, Filipinas, Israel, Irlanda, Dinamarca, Holanda, Suíça, Grécia, Islândia e Malásia), que tem sua estrutura comercial convergindo para as características comerciais de países que se encontravam inseridos no cluster em 1995.

Acredita-se que esta convergência é, em grande parte, influenciada pelo aprofundamento da especialização chinesa em eletrônicos, perda de especialização em têxteis por parte de alguns países (Figuras 2 e 3), e sobretudo, porque estes países apresentam vantagens locacionais ${ }^{15}$ que os inserem e os mantêm na dinâmica de integração produtiva, aprofundando a regionalização ${ }^{16}$ da produção em rede.

Neste aspecto, a adesão ou aprofundamento da integração produtiva e comercial (de caráter) regional sugere a existência de novos mercados para bens e serviços mais específicos. Lembrando que, conforme tratou a literatura (seção 2), os rearranjos produtivos podem ser reflexos da comunhão entre vantagens locacionais e capacidade de dinamizar estas vantagens ${ }^{17}$.

Vale recapitular que, dentre os setores e países que se inserem na lógica de integração produtiva e comercial, encontra-se também o setor de Madeira, produtos de papel, impressão e publicação de boa parte dos países da União Europeia, Malásia e Islândia na Ásia e Canadá e Estados Unidos na América do Norte, que conforme discutido na seção 3 , estes setores apresentam maior descolamento ${ }^{18}$ com os países e setores especializados em RN.

Os países e setores especializados em RN's (aos quais nos referimos), constituem outro bloco de países formado pela Austrália, África do Sul, Rússia,

(15) Vantagens comparativas locacionais são vantagens que um país possui que motivam o processo offshoring: elementos presentes na localidade que atraem partes de processos de produção de empresas de outros países.

(16) De posse das Tabelas 3 e 4, é possível notar que, principalmente para Ásia e União Europeia, os valores de valores adicionados domésticos dos setores (Produtos Químicos, Metais, Equipamentos Ópticos e Eletrônicos, Máquinas e Equipamentos e Equipamentos de Transportes), em 2009, são menores do que os valores de 1995 e os valores de VAE de 2009 são maiores do que os valores de VAE de 1995, assim como os valores de reimportação de valor adicionado doméstico.

(17) Muitos destes países (em especial dos clusters 4 e Tabela 09) possuem vantagens comparativas em recursos naturais, mas ao longo do tempo, desenvolveram outras indústrias complementares e inovadoras, causando um espraiamento pela economia.

(18) O setor de produtos alimentícios da União Europeia segue uma linha parecida. 
Chile, Noruega, Arábia Saudita, Nova Zelândia, Argentina, Brasil e Vietnã, conforme mostra a Figura 5 e Tabela 9.

A despeito de alguns destes países possuírem VCR's valor adicionados (maior que a unidade) em Metais Básicos (Tabela 9), os países reunidos no referido bloco destoam competitivamente da dinâmica da integração produtiva e comercial, por apresentarem VCR's valores adicionados em setores baseados em Recursos Naturais e caracteristicamente, possuírem valores adicionados domésticos elevados, baixos valores agregados estrangeiros nos seus produtos e inexpressiva reimportação de valor agregado doméstico (seção 3, Tabela 2 e 3).

Tais características são reforçadas diante do movimento dos países da U.E. e Ásia (no quesito integração produtiva e comercial, conforme se discutiu aqui), o que confirma a hipótese de que, em geral, para Austrália, África do Sul, Rússia, Chile, Noruega, Arábia Saudita, Nova Zelândia, Argentina, Brasil e Vietnã, há um descompasso entre os recursos naturais e Cadeias Globais de Valor, expressos numa fragilidade de oportunidades de encadeamentos setoriais para uma estrutura mais moderna de indústria RN.

Nesta lógica, ao recuperar as contribuições de Carlota Perez, sob um olhar para América Latina, os países especializados em RN's estão menos propensos a aproveitar as "janelas de oportunidades" para exploração de suas vantagens em recursos naturais e desenvolver capacidades sobre competências tecnológicas e produtivas que gradualmente avançam para tecnologias mais complexas e para atividades mais especializadas e de maior valor agregado.

\section{Considerações finais}

O presente artigo objetivou caracterizar a especialização em recursos naturais no contexto de mudanças no comércio internacional, voltadas para a intensificação dos processos de produção em rede. Com base na decomposição das exportações brutas e Análise de Cluster, foi possível perceber que os padrões de comércio, de fato, estão se voltando para a lógica de produção em rede, no entanto, esta tendência não indica mudanças na natureza comercial de países especializados em Recursos Naturais - tais como Austrália, África do Sul, Rússia, Chile, Noruega, Arábia Saudita, Nova Zelândia, Argentina, Brasil e Vietnã - significando que as vantagens comparativas continuam relacionadas ao comércio de bens finais (insumo básico com baixo grau de valor adicionado estrangeiro e reimportação de valor adicionado doméstico).

Assim, a estratégia de inserção e upgrading na produção em rede (estratégia de baixo para cima, conforme nomeia a literatura), tecnicamente se configura como única opção e, assim mesmo, com poucas chances de sucesso. Ao se retomar as contribuições de Carlota Perez - qual seja a necessidade dos países especializados 
em RN, em especial a América Latina, de desenvolver a sua "indústria de processos" (diversificação setorial) e concomitantemente, galgar espaços de oportunidades de inovação e competências tecnológicas que poderão culminar em inserção em novos paradigmas (Ciências dos Materiais, etc.) -é possível concluir que o aproveitamento das janelas de oportunidades por parte destes países fica mais distante de sua realidade. Nestas condições, ficam os Recursos Naturais restringidos tecnicamente, dadas as dificuldades de internalização de processos mais básicos de transformação de recursos naturais que gerem encadeamentos setoriais de modo a desenvolver novas competências.

\section{Referências bibliográficas}

ALENCAR, B. J.; BARROSO, L. C; ABREU, J. F. Análise multivariada de dados no tratamento da informação espacial: uma abordagem com análise de agrupamentos. Sistemas, Cibernética e Informática, v. 10, n. 2, 2013. Disponível em: http://www.iiisci.org/journal/CV\$/risci/pdfs/CA215JK13.pdf. Vários acessos.

ALTENBURG, T. Donor approaches to supporting pro-poor value chains. Bonn: German Development Institute, 2007.

BALDWIN, R. Global supply chains: why they emerged, why they matter, and where they are going Centre for Trade and Economic Integration. Geneva: Graduate Institute of International and Development Studies, Geneva and Oxford University, 2012. (CTEI Papers).

BARBALETTA, F.; ROBERT, V.; YOUGEL, G. Algunos comentarios sobre el artículo "Dinamismo tecnológico e inclusión social mediante una estrategia basada en los recursos naturales", de Carlota Perez. Revista Econômica, v. 14, n. 2, 2012.

BEADREAU, B. C. Vertical comparative advantage. The International Trade Journal, v. 25, n. 3, 2011.

BELZBERG, A. Trending trades: investigating comparative advantage throught vertical specialization in supply chains. Department of Economic, Pomona College, Charemont, May 2014.

BRESSER-PEREIRA, L. C. Do Iseb e da Cepal à teoria da dependência. In: TOLEDO, Caio Navarro (Org.). Intelectuais e política no Brasil: a experiência do Iseb. São Paulo: Revan, 2005. p. 201-232.

BRESSER-PEREIRA, L. C. Maldição dos recursos naturais. Folha de São Paulo, 6 jun. 2005a.

BRESSER-PEREIRA, L. C.; GALA, P. S. Macroeconomia estruturalista do desenvolvimento. São Paulo: FGV, nov. 2010 (Texto para Discussão, n. 275). 
BUSSAB, W. de O.; MIAZAKI, S. E.; ANDRADE, D. F. Introdução à análise de agrupamento. In: SIMPÓSIO BRASILEIRO DE PROBABILIDADE E ESTATÍSTICA, 9, São Paulo, 1990.

CHENERY, H. Vantagem comparativa e medidas de política para o desenvolvimento. In: SAVASINI, J.; MALAN, P. (Org.). Economia internacional. Ed. Saraiva, 1973. (Série Anpec de Leituras de Economia).

CRUZ, C. D.; REGAZZI, A. J. Divergência genética. In: CRUZ, C. D.; REGAZZI, A. J. Métodos biométricos aplicados ao melhoramento genético. Viçosa: UFV. Imprensa Universitária, 1997. cap. 6, p. 287-324.

ESTEVADEORDAL, A.; BLYDE, J.; SUOMINEN, K. As cadeias globais de valor são realmente globais? Políticas para acelerar o acesso dos países às redes de produção internacionais. 2013. Disponível em: http://www.funcex.org.br/publicacoes/rbce/material/rbce/115_AEJBKS.pdf.pdf.

Acesso em: 15 maio 2013.

EVERITT, B. S. Cluster analysis. London: Edward Arnold, 1993.

FEENSTRA, R. C. Integration of trade and disintegration of production in the global economy. Journal of Economic Perspectives, v. 12, n. 4, p. 31-50, 1998.

GALA, P. Política cambial e macroeconomia do desenvolvimento. Tese (Doutorado)-Escola de Economia da Fundação Getúlio Vargas, São Paulo, maio 2006.

GEREFFI, G.; HUMPHREY, J.; STURGEON, T. The governance of global value chains. Review of International Political Economy, v. 12, n. 1, p. 78-104, 2005.

GIMENES, F. R.; GIMENES, R. M. T.; OPAZO, M. A. U. Os processos de integração econômica sob a ótica da análise estatística de agrupamento. FAE, Curitiba, v. 7, n. 2, p. 19-32, jul. /dez. 2003.

GROSSMAN, G. M.; HELPMAN, E. Innovation and growth in the global economy. MIT Press. 1991.

HAUSMANN, R.; HIDALGO, C. The network structure of economic output. Journal of Economic Growth, v. 16, n. 4, p. 309-342, Springer 2011.

HIRSCHMAN, A. The strategy of economic development, New Haven: Yale University, 1958.

JOHNSON, E.; NOGUERA, G. Accounting for intermediates: production sharing and trade in value-added. Journal of International Economics, v. 86, n. 2, p. 224236, Mar. 2012.

JOHNSON, R. A.; WICHERN, D. W. Aplied multivariate statistical análysis. Prentice-Hall. Inc., 1982. 
JONES, R.; KIERZKOWSKI, H. A framework for fragmentation. 2000.(Tinbergen Institute Discussion Paper, n. 056/2).

KALDOR, N. (1966). Causes of the slow rate of economic growth of the United Kingdom. In: KING, J. E. Economic growth in theory and practice: a Kaldorian perspective. Cambridge: Edward Elgar, 1994. p. 279-318.

KAPLINSKY, R.; MORRIS, M. A handbook for value chain research. Prepared for the International Development Research Centre (IDRC), 2001. p. 1-109.

KOOPMAN, R. et al. Give credit where credit is due: tracing value added in global production chains. Cambridge, MA: NBER, Sept. 2010. (Working Paper, n. 16.426).

KOOPMAN, R.; WANG, Z.; WEI, S. J. Tracing value added and double counting in gross exports. Cambridge MA: National Bureau of Economic Research, 2012. (NBER Working Paper, n. 18579).

LALL, S.; ALBALADEJO, M.; MESQUITA M. M. Latin American industrial competitiveness and the challenge of globalization. Inter-American Development Bank, 2004. (IDB Publications, n. 8551).

LANDIM, P. M. B. Análise estatística de dados geológicos. São Paulo: Fundação Editora da Unesp, 2001. 226p.

LUCAS, R. On the mechanics of economic development. Journal of Monetary Economics, v. 22, n. 1, p. 3-42, 1988.

MACIEL, G da C. A. Recursos naturais e desenvolvimento econômico: benção, maldição ou oportunidade? 291f. Tese (Doutorado)-Universidade Federal do Rio de Janeiro, 2015.

MARDIA, K. V.; KEMT, J. T.; BIBBY, J. M. Multivariate analysis. New York: Academic Press, 1989.

MARIN, A.; NAVAS, A. L.; PEREZ, C. The possible dynamic role of natural resource-based networks in Latin American development strategies. Disponível em: http://www.ids.ac.uk/publication/the-possible-dynamic-role-of-natural-resourcebased-networks-in-latin-american-development-strategies. Vários Acessos.

MOREIRA, U. Teorias do comércio internacional: um debate sobre a relação entre crescimento econômico e inserção externa. Rev. Econ. Polit., São Paulo, v. 32, n. 2, abr./jun. 2012.

MOTTA VEIGA, P. M.; RIOS, S. P. Cadeias de Valor baseadas em recursos naturais e upgrading de empresas e setores: o caso da América do Sul. Breves Cindes, Rio de Janeiro, ago. 2008. 
NONNENBERG, M. J. B. Participação em cadeias globais de valor e desenvolvimento econômico. Boletim de Economia e Política Internacional, BEPI, n. 17, maio/ago. 2014.

OLIVEIRA, Susan Elizabeth Martins Cesar de. Cadeias globais de valor e os novos padrões de comércio internacional: uma análise comparada das estratégias de inserção de Brasil e Canadá. 2014. Disponível em: http://funag.gov.br/loja/download/1124. Acesso em: 26 out. 2016.

PEREZ, C. Dinamismo tecnológico e inclusion social em America Latina: uma estratégia de desarrollo productivo basada em los recursos naturales. Revista Cepal, n. 100.p. 123-145, abr. 2010.

PIETROBELLI, C.; STARITZ, C. Challenges for global value chain interventions in Latin America. Competitiveness and Innovation Division. Inter-American Development Bank, 2013. (Technical Note, n. IDB-TN-548).

PREBISCH, R. El desarrollo económico de la América Latina y algunos de sus principales problemas. Desarrollo Económico, v. 26, n. 103, p. 479-502, 1949.

REDDING, S. Dynamic comparative advantage and the welfare effects of trade. Oxford Economic Papers, v. 51, n. 1, p. 15-39, 1999. Available at http://ideas.repec.org/a/oup/oxecpp/v51y1999i1p15-39.html.

REINERT, E. Developmentalism. The Other Canon Foundation and Tallinn University of Technology. TUT Ragnar Nurkse School of Innovation and Governance, 2010. (Working Papers in Technology Governance and Economic Dynamics, n. 34).

REIS, C. F.de B. Recursos naturais e desenvolvimento econômico: da especialização à diversificação produtiva e exportadora nos Seanic's. 232f. Tese (Doutorado) Universidade Federal do Rio de Janeiro, 2012.

RIBEIRO, L. C. de S.; ROCHA, G. de B. Interdependência produtiva e estratégias de desenvolvimento para o Estado da Bahia. Disponível em: http://www.seer.ufu.br/index.php/revistaeconomiaensaios/article/viewFile/26324/1 4352.

RIPPEL, R.; LIMA, J. F.; BORGES, R. G. Cadeias produtivas no desenvolvimento regional: o caso de Toledo no Oeste do estado do Paraná. In: ENCONTRO DE ECONOMIA PARANAENSE, 5. Anais... Curitiba: UFPR, 2007, p. 1-21.

ROCHA, F. Comentários a "Una visión para América Latina: Dinamismo tecnológico e inclusión social mediante una estrategia basada en los recursos naturales", de Carlota Perez: a Lei de Engel. Revista Econômica, Niterói, v. 14, n. 2, p. 63-72, dez. 2012. 
ROMER, P. M. Endogenous technological chance. Journal of Political Economy, v. 98, n. 5, p. S71-S102, Oct. 1990.

ROSS, M. The political economy of the resource curse. World Politics, v. 51, p. 297-322, 1999.

SINGER, H. W. The distribution of gains between investing and borrowing countries. The American Economic Review, v. 40, n. 2, p. 473-485, 1950.

STURGEON, T.; KAWAKAMI, M. Global value chains in the electronics industry. Washington, DC: The World Bank, 2010. (Policy Research Working Paper, n. 5417).

THIRLWALL, A. P. The balance of payments constraint as an explanation of international growth rate differences. BNL Quarterly Review, v. 32, p. 45-53, 1979.

UNCTAD. Global value chains: investment and trade for development. World Investment Report, 2013. Disponível em: http://unctad.org/en/PublicationsLibrary/wir2013 en.pdf. Vários acessos.

VAN LONG, N.; RIEZMAN, R.; SOUBEYRAN, A. Fragmentation and services: fragmentation and services in the modern economy. The North American Journal of Economics and Finance, v. 16, n. 1, p. 137-152, 2005.

WORLD TRADE ORGANIZATION (WTO); THE INSTITUTE OF DEVELOPING ECONOMIES (IDE-JETRO). Trade patterns and global value chains in East Asia: from trade in goods to trade in tasks. 2011. Disponível em https://www.wto.org/english/res e/booksp e/stat tradepat globvalchains e.pdf. Acesso em: 20 abr. 2015.

ZHANG, L.; SCHIMANSKI, S. Cadeias globais de valor e países em desenvolvimento. Boletim de Economia e Política Internacional | BEPI, n. 18, set./dez. 2014. . Disponível em: http://www20.iadb.org/intal/catalogo/PE/2015/15323.pdf. Vários acessos. 